NBER WORKING PAPER SERIES

\title{
THE 2004 GLOBAL LABOR SURVEY: WORKPLACE INSTITUTIONS AND PRACTICES AROUND THE WORLD
}

\author{
Davin Chor \\ Richard B. Freeman \\ Working Paper 11598 \\ http://www.nber.org/papers/w11598
NATIONAL BUREAU OF ECONOMIC RESEARCH
1050 Massachusetts Avenue
Cambridge, MA 02138
August 2005

The Global Labor Survey (GLS) was conducted under the auspices of the Labor and Worklife Program at the Harvard Law School (LWP). The data will be made available at www.law.harvard.edu/programs/lwp/. We thank Elaine Bernard at the LWP for project support; Jean Roth (NBER), Brian Wong and Kah Keng Tay for technical assistance related to the GLS website; the staff of the Berkman Center for Internet and Society at the Harvard Law School for hosting the web server; Lorette Baptiste and Alida Castillo for survey translations; Eric Lee of www.labourstart.org for Internet publicity; and the International Industrial Relations Organization (IIRO) for sharing their e-mail contact list with us. Alisa Di Caprio assisted in the initial drafting of the survey questions. Chor also thanks several classmates for their thoughtful comments and linguistic abilities: Filipe Campante, Quoc-Anh Do, Kate Emans and Han Li. All errors are our own. Last but certainly not least, we thank all respondents and contacts in labor communities around the world for their time and patience. Comments can be directed to chor@ post.harvard.edu or freeman@ nber.org. The views expressed herein are those of the author(s) and do not necessarily reflect the views of the National Bureau of Economic Research.

(C)2005 by Davin Chor and Richard B. Freeman. All rights reserved. Short sections of text, not to exceed two paragraphs, may be quoted without explicit permission provided that full credit, including $\odot$ notice, is given to the source. 
The 2004 Global Labor Survey: Workplace Institutions and Practices Around the World Davin Chor and Richard B. Freeman

NBER Working Paper No. 11598

August 2005

JEL No.

\section{ABSTRACT}

The 2004 Global Labor Survey (GLS) is an Internet-based survey that seeks to measure de facto labor practices in countries around the world, covering issues such as freedom of association, the regulation of work contracts, employee benefits and the prevalence of collective bargaining. To find out about de facto practices, the GLS invited labor practitioners, ranging from union officials and activists to professors of labor law and industrial relations, to report on conditions in their country. Over 1,500 persons responded, which allowed us to create indices of practices in ten broad areas for 33 countries. The GLS' focus on de facto labor practices contrasts with recent studies of de jure labor regulations (Botero et al., 2004) and with more limited efforts to measure labor practices as part of surveys of economic freedom (Fraser Institute) and competitiveness (World Economic Forum).

Although our pool of respondents differs greatly from the conservative foundations and business leaders who contribute respectively to the Fraser Institute and World Economic Forum reports, the GLS and the labor market components of the economic freedom and competitiveness measures give similar pictures of labor practices across countries. This similarity across respondents with different economic interests and ideological perspectives suggests that they are all reporting on labor market realities in a relatively unbiased way. As a broad summary statement, the GLS shows that practices favorable to workers are more prevalent in countries with high levels of income per capita; are associated with less income inequality; are unrelated to aggregate growth rates; but are modestly positively associated with unemployment.

Davin Chor

Department of Economics

Harvard University

Cambridge, MA 02138

chor@fas.harvard.edu
Richard B. Freeman

NBER

1050 Massachusetts Avenue

Cambridge, MA 02138-5398

freeman@ nber.org 


\section{INTRODUCTION}

This paper reports on an Internet-based survey designed to collect information on the state of workplace practices from labor experts and practitioners around the world -- the 2004 Global Labor Survey (GLS). This effort comes at a time of intense debate over the impact of labor market institutions on economic outcomes, in which analysts use diverse indices of practices and/or measures of de jure labor regulations to examine the link between the labor market and general economic success. On one side of the debate are economists and policymakers who attribute some of the economic problems in advanced countries and failures of developing countries to labor market rigidities that result from government regulations or union activities. On the other side are economists and policy-makers who argue that the redistributive and other benefits from regulations and unionism exceed whatever costs they create in the form of less flexible markets, and that absent institutions, labor markets do not function as perfect invisible hand mechanisms.

For the advanced countries, the OECD Jobs Study (1994) argued that substantial labor market reforms were required to cure the European Union's economic problems. This view found support in some empirical studies, but also led to further work that stressed the frailty of many cross-country empirical studies (see Freeman, 2005, for a review of this debate). For developing countries, there has been a similar debate. Economists at the World Bank and IMF have worried that labor regulations impede the success of economic reforms (Forteza and Rama, 2002), and often call for greater labor market flexibility to ease adjustment problems; on the other hand, those associated with the ILO take the opposite perspective. ${ }^{1}$ Evidence that Indian states with more pro-labor regulations have performed less well in output and employment in the

\footnotetext{
${ }^{1}$ For example, Baccaro et al. (2003) present a research proposal to try to understand and quantify how labor institutions, such as unions and collective bargaining, fit within the larger fabric of social dialogue in an economy.
} 
formal manufacturing sector than other Indian states without improving the well-being of workers raises questions about the value of such regulations within developing countries (Besley and Burgess, 2004). But evidence from other studies has moved the World Bank, the InterAmerican Development Bank, and the Asian Development Bank, among others, toward nuanced views about the contribution of labor institutions in development (World Bank, 1995; InterAmerican Development Bank, 2005).

By developing new and potentially more accurate measures of labor practices, the GLS should improve the quality of analysis, and help economists and others reach firmer conclusions about the positive or negative effects of given practices on aggregate economic performance.

\section{Overview}

The GLS assesses the current state of workplace practices and institutions by surveying practitioners and labor relations experts who have firsthand knowledge and experience of de facto practices, as opposed to de jure laws or regulations. The GLS was run as an Internet survey in 2004 under the auspices of the Labor and Worklife Program (LWP) at the Harvard Law School. The survey covered many aspects of labor institutions, including employment regulations, the freedom of association, and employee benefits. The question format used a seven-point scale that has worked well in surveys of business leaders in the World Economic Forum's Global Competitiveness Report (GCR). We invited members of the International Industrial Relations Organization (IIRO), and subscribers and users of www.labourstart.org, the news portal dedicated to labor and union affairs, to the GLS website to answer the survey. In addition, we contacted persons connected with the LWP and the Harvard Trade Union Program to boost responses in countries where we otherwise had trouble getting sufficient respondents. 
These efforts produced nearly 1,600 completed surveys from 77 states/territories. However, a disproportionate number of responses came from advanced English-speaking countries and only a few came from developing countries. If respondents from the same country had given widely different answers, the small numbers would have created problems for the GLS, but statistical analyses shows that the responses to questions were relatively similar within countries, while varying greatly across countries. Thus, only a few respondents per country are needed to give a consistent picture of labor practices. In this report, we focus on a subset of 33 countries in which we had at least 4 responses. We amalgamated questions to construct indicators of conditions in the 33 countries under seven headings: General Economic Situation; Role of World Bank \& IMF; Labor Market Conditions; Freedom of Association \& Collective Bargaining; Labor Disputes; Employment Regulations \& Working Conditions; and Employee Benefits. In addition, we report the respondents' estimates of the percentage of workers in the informal sector, the percentage of workers in unions, and the percentage covered by a collective bargaining agreement.

Over $60 \%$ of the respondents to the GLS were union officials or labor activists, most holding pro-labor positions on issues. This raises questions about potential bias in answers about labor market practices. To examine whether the orientation of respondents affected their reports, we analyzed the relationship between respondents' views on some political and economic issues and their responses to the GLS questions. We found only a modest relation, implying that any such effect was small. Still, we calibrated answers to adjust for the attitudes of respondents. Finally, we compared the calibrated country indices from the GLS with other measures from surveys whose respondents were likely to have a pro-business or conservative bias: the World Economic Forum's Global Competitiveness Report (GCR), which surveys business executives in 
their country of operation, and the Fraser Institute's Economic Freedom of the World (EFW) study. The respondents on the GLS and those on these surveys gave similar pictures of labor practices. This reflects well on the validity of all of the studies, suggesting that they tap a common component of information on labor market conditions rather than hinge on the right-left or labor-management views of respondents. The only difference we detected among the surveys was the opposite of what we anticipated: GLS respondents had a modestly more positive view of the labor friendliness of practices than business executives.

We also compared the GLS indicators with the de jure measures of labor market regulation compiled by Botero et al. (2004), and subsequently updated by the World Bank's Doing Business database. The correlation between the GLS and the Botero et al. (2004) data is lower than that between the GLS and the EFW and GCR indicators, presumably reflecting the divergence between regulations and implementation.

Finally, we examined how the GLS measures of labor practices varied with the economic performance of these countries. We found that countries whose practices are more favorable to workers had relatively higher levels of income per capita and lower Gini coefficients. In addition, pro-labor practices were unrelated to aggregate growth rates, but were modestly associated with higher rates of unemployment. These patterns fit reasonably well with the bulk of studies that relate economic outcomes to measures of labor market institutions.

In sum, the inaugural GLS demonstrates that it is possible to gather detailed, valid information on labor practices from labor experts and practitioners in different countries at low cost through the Internet. The major weakness of the 2004 survey was the shortfall of responses from many developing countries. This can be attributed to the fact that our e-mail contact lists included fewer practitioners from developing countries, and to weak Internet connections in 
some countries that made it difficult for persons to respond. This suggests the need for expanding the reach of the GLS, possibly by supplementing the sample through non-Internet-based surveying with the assistance of country-based organizations, who could invite practitioners and experts to fill out the surveys as part of a conference or at some venue with broadband or other fast links. In addition, we would have liked more responses from personnel and labor relations practitioners in the business community. Despite these shortcomings, the diagnostics and the crosschecks with other data sources showed that the GLS did indeed capture useful systematic information for the purposes of cross-country comparisons of labor market institutions.

Since measures of actual conditions and practices are necessary to monitor the progress of countries towards meeting difficult-to-measure human development objectives, such as abolishing child labor, improving safety standards in the workplace (for example, Bohning, 2003), and raising labor standards more broadly, the GLS's "ask the practitioners and experts" design offers a distinct way to improve monitoring at the country level. ${ }^{2}$ The design also offers a way to obtain objective measures of labor practices in place of subjective categorizations that could help resolve open issues in the on-going debate about labor institutions.

\section{SURVEY METHODOLOGY}

The GLS begins by asking respondents their country of expertise, years of involvement with labor affairs in this country, and occupation (options included academic, government official, union activist, among others). ${ }^{3}$ The survey then moves to six modules of questions about economic and labor issues, as summarized in Table 1: General Economic Situation; The

\footnotetext{
${ }^{2}$ Such assessments of the protection of workers' rights and dignity can have operational consequences. For example, the California Public Employees Retirement System (CalPERS) commissioned Verité (2003) to draft a report on labor conditions around the world, on which it reportedly based some of its emerging market investment decisions. ${ }^{3}$ In addition, 205 respondents identified themselves as Labourstart correspondents on Question 0.04 of the survey.
} 
Labor Market; Freedom of Association \& Collective Bargaining; Labor Disputes; Employment

Regulations \& Working Conditions; and Employee Benefits. Several of the question categories and some questions were adapted from the GCR or from Botero et al. (2004) to facilitate comparisons. The last module asks respondents about their political and policy leanings: whether they identify themselves as more left-wing or right-wing; their views on government involvement in economic policy; whether the state or workers should bear most of the responsibility for ensuring a basic standard of living; and whether international trade agreements should contain labor clauses. These questions allow us to identify the orientation of respondents and examine whether that affected their answers. (The GLS questions are reproduced in their entirety in Appendix Table 1.)

The survey instrument uses the question design that has worked successfully in the GCR survey of business executives. Respondents are asked to register their assessments on a scale from 1 to 7, with the following being a sample question:

\section{Protection of the right to form a union in your country is}

Weak or non-existent

\begin{tabular}{|l|l|l|l|l|l|l|}
\hline 1 & 2 & 3 & 4 & 5 & 6 & 7 \\
\hline
\end{tabular}

Equal to the worlds' most stringent

Selecting 1: means you agree completely with the answer on the left-hand side Selecting 7: means you agree completely with the answer on the right-hand side

Selecting 2: means you largely agree with the left-hand side answer Selecting 3: means you somewhat agree with the left-hand side answer Selecting 4: means your opinion is indifferent between the two answers Selecting 5: means you somewhat agree with the right-hand side answer Selecting 6: means you largely agree with the right-hand side answer

We designed the GLS questions so that the left side answer (a response of 1) could be broadly identified with a pro-business set of institutions or workplace conditions, while the right side 
answer (a response of 7) corresponded to pro-labor conditions. This question format helped to minimize the time to complete the survey. ${ }^{4}$ In addition, three questions asked for quantitative estimates, for example, on the percentage of workers in the informal sector. The survey instructions encouraged respondents to skip questions that they were not in a position to answer. The default answer for all questions was set at "N/A" (for no response).

\section{Survey Implementation}

The GLS was hosted at: http://gls.law.harvard.edu, with the assistance of the Berkman Center for Internet and Society at the Harvard Law School. The survey was launched in February 2004 with an announcement on http://www.labourstart.org, an online news service on trade unionism around the world. ${ }^{5}$ We also sent e-mail invitations to take the survey to members of the International Industrial Relations Organization (IIRO) and the European Industrial Relations Observatory (EIRO). ${ }^{6}$ Subsequently, we contacted labor activists and academics in specific countries through the Harvard Law School Labor and Worklife Program. At its launch, the GLS was available in three languages, English, French and Spanish; a Portuguese version was added in November 2004.

\section{SUMMARY STATISTICS, DIAGNOSTICS AND CALIBRATION}

The GLS received 1,582 responses by late November 2004, with respondents from 77 states/territories around the world. Table 2 lists these countries and the number of responses from each. The vast majority of responses were from English-speaking OCED countries (Australia,

\footnotetext{
${ }^{4}$ For the sample of 33 countries with more than 4 responses, the mean time to complete the survey was approximately 20 minutes, while the median time was just over 14 minutes. This appears to be a reasonable amount of time to complete the 82 questions in the survey conscientiously, an important consideration especially for developing countries where Internet access might be relatively expensive.

${ }^{5}$ Labourstart has over 15,000 subscribers and over 230 volunteer correspondents.

${ }^{6}$ The ILO provided us with the relevant e-mail information for the IIRO, while the contact information for the EIRO was obtained from: http://www.eiro.eurofound.eu.int/contact.html.
} 
Canada, the United Kingdom and the United States), but there were also responses from developing countries such as China (7), India (15), Mexico (7), Peru (14), and South Africa (10). As noted, the bulk of our analysis concentrates on the 33 states that had 4 or more responses, as listed at the bottom of Table 2. These 33 states made up 1,514 of the 1,582 responses received.

Table 3 shows that the typical respondent (for the full sample of 1,582 responses) was a labor activist or union official with substantial experience in labor affairs. ${ }^{7}$ Almost two-thirds of respondents reported that they had more than 10 years of experience monitoring or participating in labor issues in their country; and an additional $15.6 \%$ said that they had between 5-10 years of experience (Table 3A). In addition, Table 3B shows that labor union officials and activists made up just over three-fifths (60.8\%) of the respondents, followed by academics (18.3\%) and government officials (4.4\%). Consistent with this background, most respondents gave pro-labor and left-oriented assessments on questions about their personal views on economic and political issues (Table 3C). On a 1 to 7 scale, where 1 was the most conservative and 7 the most left-wing orientation, scores averaged 5.2 to 6.4, across Questions 7.01 to 7.04 .

\section{Statistical Diagnostics}

For the GLS to provide useful information about differences in labor practices across countries, responses to survey questions must vary significantly across countries while showing consistency within countries. As a first test of whether GLS respondents agreed about their country's conditions, we calculated the $r_{\mathrm{WG}}$ statistic for inter-rater reliability based on James, Demaree and Wolf (1984). This statistic measures the extent of agreement in the answers among respondents from the same country compared to a specified null hypothesis. We calculated this

\footnotetext{
${ }^{7}$ The percentages in Table 3 are similar when the sample is restricted to the 33 countries with at least 4 responses.
} 
statistic for clusters of questions in our labor market indices separately for each country.

Specifically, for a given module of $J$ questions, the $r_{\mathrm{WG}}$ statistic was calculated as:

$$
\mathrm{r}_{\mathrm{WG}} \equiv \frac{J\left[1-\left(s_{x}^{2} / \sigma_{N}^{2}\right)\right]}{J\left[1-\left(s_{x}^{2} /{\sigma_{N}}^{2}\right)\right]+\left(s_{x}^{2} / \sigma_{N}^{2}\right)}
$$

where $s_{x}{ }^{2}$ denotes the mean variance of observed responses across the $J$ questions in the module, and $\sigma_{N}^{2}$ is the variance of the null distribution against which we are comparing the observed distribution of responses. For the null, we adopt a discrete uniform distribution, so that $\sigma_{N}^{2}$ is the variance we would observe if the respondents had picked their answers randomly by giving each possible response equal probability. ${ }^{8}$

The test statistics reported in Table 4A show a high degree of agreement among respondents for most countries. The $r_{W G}$ statistic fell below the critical value of 0.7 for only the handful of countries listed in the rightmost column of the table. The values were lower for Module 7, which asked for personal views on issues rather than factual matters. ${ }^{9}$

Did the GLS respondents agree more or less on labor practices in their country compared to respondents on the widely used Global Competitiveness Report (GCR), which uses the same 1-to-7 scoring system? To answer this question, we calculated $r_{W G}$ statistics using data on individual respondents from the $2002 \mathrm{GCR} .^{10}$ The $\mathrm{r}_{\mathrm{WG}}$ values ranged from 0.81 to 0.96 for the GCR "Human Resources” modules, which had nine questions on labor-related issues -reassuringly in the same ballpark as most of our $\mathrm{r}_{\mathrm{WG}}$ statistics for the GLS. The high GLS $\mathrm{r}_{\mathrm{WG}}$

\footnotetext{
${ }^{8}$ For the questions on the seven-point scale, this means picking each response with probability $1 / 7$, which gives $\sigma_{N}^{2}$ $=4$. For the three questions that seek percentage estimates, this means picking each of the 5 options $(0-20 \%, 21$ $40 \%, \ldots, 81-100 \%$ ) with probably $1 / 5$ each; in this case, $\sigma_{N}^{2}=2$. For these quantitative questions, we set $J=1$ in the expression for the $\mathrm{r}_{\mathrm{WG}}$ statistic.

${ }^{9}$ It should be acknowledged, however, that the agreement statistics were much poorer for the GLS questions that sought quantitative estimates, namely questions $2.10,3.01$ and 3.08. This suggests that it is not easy to get a good consensus gauge of these percentages even from labor market insiders.

${ }^{10}$ Andrew Warner made the raw data for the 2002 GCR available to us. There were 97 countries in the GCR sample, where the response count ranged from 10 (Israel) to 250 (Russia).
} 
statistics and their similarity to the GCR $\mathrm{r}_{\mathrm{WG}}$ statistics give us confidence that the GLS accurately identified country workplace practices and institutions. ${ }^{11}$

As a second test diagnostic, we computed the Intra-class Correlation Coefficient (ICC):

$$
\mathrm{ICC} \equiv \frac{\sigma_{B}^{2}}{{\sigma_{B}}^{2}+\sigma_{W}^{2}}=\frac{M S_{B}-M S_{W}}{M S_{B}+(k-1) M S_{W}}
$$

where $\sigma_{W}^{2}$ is the within-country variance and ${\sigma_{B}}^{2}$ is the between-country variance in responses to questions. The ICC thus measures the share of total variability accounted for by the betweencountry component. Thus, the higher the ICC, the more the variation in individual responses reflects differences in assessments across countries rather than disagreements among individuals within country. As the equation shows, the ICC can be re-written in terms of $M S_{B}$ and $M S_{W}$, the between-country and within-country mean sum of squares from a standard ANOVA table, and $k$, which depends on the mean number of respondents per country (Shrout and Fleiss 1979). ${ }^{12}$ Based on the ICC, we also computed the following Spearman-Brown (SB) prediction formula:

$$
\mathrm{SB} \equiv \frac{k * I C C}{1+(k-1) * I C C}
$$

which measures the estimated reliability of the country-averaged scores. ${ }^{13}$

We calculated the ICC and SB statistics for each individual question. Table 4B gives summary values of these statistics for each part of the GLS. The ICC values for the first six modules of the survey ranged between 0.06 and 0.57 , with the corresponding SB reliability statistic ranging between 0.69 and 0.98 . By way of comparison, the ICC values for the 2002 GCR questions on "Human Resources" were between 0.22 and 0.52 , with the SB reliability

\footnotetext{
${ }^{11}$ In computing the $\mathrm{r}_{\mathrm{WG}}$, we excluded responses that were only partially filled in. We also checked the data to ensure that no consecutive sets of survey responses were carbon copies of one another.

${ }^{12}$ Here $k=\left(N-\Sigma_{i} n_{i}^{2} / N\right) /(m-1)$, where $N$ is the total number of individual observations, $n_{i}$ is the number of observations from country $i$, and $m$ is the total number of countries in the sample.

${ }^{13}$ See Winer, Brown and Michels (1991). The ICC and SB are computed using the "loneway" function in STATA.
} 
statistic ranging between 0.94 and 0.98 . This contrast shows greater dispersion in the withincountry reliability in the GLS than in the GCR, due in large part to the smaller sample and more unbalanced observation counts across countries in the GLS. Still, about one half of the GLS questions yielded ICC values comparable to those from the 2002 GCR (falling between 0.22 and 0.52). Not surprisingly, the ICC and SB statistics of relative variability are low for Module 7 of the GLS, which asked for personal views rather than facts about labor conditions.

\section{Calibration for Modal Respondent}

As noted, the sample of respondents to the GLS consists disproportionately of union officials and activists, and of persons with a left orientation. If respondents with particular attributes gave strikingly different answers to questions for the same country, the particularities of respondents could be biasing the patterns among countries. To control for this possibility, we ran a multivariate regression linking responses on the GLS to the characteristics and attitudes of respondents for the 33 countries with at least 4 respondents:

$$
\begin{aligned}
& y_{c i}(Q)=\text { Dcountry }_{c}+\text { Doccupation }+ \text { Dexperience }+ \text { Dlabourstart }+\ldots \\
& \ldots+\beta_{1} \times q 701+\beta_{2} \times q 702+\beta_{3} \times q 703+\beta_{4} \times q 704+v_{c}+\varepsilon_{c i}
\end{aligned}
$$

Here, $y_{c i}(Q)$ is the response given by respondent $i$ from country $c$ for question $Q$; the $D$ variables are dummy variables for countries, Dcountry $_{c}$; occupation, Doccupation; ${ }^{14}$ years of experience with labor affairs, Dexperience ${ }^{15}$ and whether the respondent is a Labourstart correspondent, Dlabourstart. ${ }^{16}$ The measures of left-right orientation are responses on $q 701$ through $q 704$, which asked for individual's personal positions on political and economic issues. The regressions were estimated to allow for standard errors clustered by country $\left(v_{c}\right)$.

\footnotetext{
${ }^{14}$ The dummies are for the eight occupational categories listed in Question 0.03 , plus an additional category for no response. All responses "Other" were lumped as one category.

${ }^{15}$ The dummies are for: Less than 1 year of experience; 1 to 5 years of experience; 5-10 years of experience; more than 10 years of experience; plus a category for "NA" (no response).

${ }^{16}$ This included an additional dummy for the category "NA" (no response).
} 
To correct for differences in respondents' attitudes, we used the above regressions to estimate for each question the response that would have been given by a hypothetical modal respondent with neutral political and economic views. The modal profile corresponded to that of a "Labor union official" with "More than 10 years" of experience, who was not a Labourstart correspondent. Neutral views corresponded to those of someone who gave the midpoint answer ( 4 on the seven-point scale) for each of the Module 7 questions. These calculations gave us estimated scores (as well as standard errors) for each question, which we then averaged by module to obtain country aggregates. In this manner, we constructed 10 summary indices of labor conditions. Table 5 gives these indices by country, sorted in descending order of score. ${ }^{17}$ We mark the indices for which the $\mathrm{r}_{\mathrm{WG}}$ statistic was smaller than the critical value of 0.7 in Table 4A by an asterisk to indicate that the score was based on a low level of inter-rater agreement.

How did these calibrated indices compare with a simpler uncalibrated within-country mean of respondent scores? Looking across the 75 questions in Modules 1-6 of the GLS, the minimum cross-country correlation between the calibrated and uncalibrated scores was 0.840 , while the mean correlation was a very high 0.963 . This high correlation implies that the ordering of country scores is largely preserved under different ways of aggregating the raw survey data. ${ }^{18}$ The rest of this paper uses the indices calibrated to account for respondent characteristics.

\section{Effect of Respondent Orientation}

We assess in Table 6 how much the political orientation and attitudes of individual respondents affected the overall assessments of labor practices. This table reports the results

\footnotetext{
${ }^{17}$ Values for each individual question are available upon request.

${ }^{18}$ The country rankings for all the labor market indicators were virtually identical if the calibration regressions were run by weighting observation $y_{c i}(Q)$ by the number of responses from country $c$. For the 75 questions in Modules 16 of the GLS, the minimum cross-country correlation between the scores calibrated with weights and that calibrated without weights was 0.993 , while the mean correlation was 0.998 . Tables based on the weighted calibration procedure or on the uncalibrated procedure are available upon request.
} 
from regressions of our calibrated indices on various measures of individual respondent characteristics, including the questions on political attitudes. The regression coefficients on the Module 7 variables show little relation to how the respondents reported conditions: Only 3 of these 28 regression coefficients are significant at a $10 \%$ level, while the vast majority of the occupational coefficients are also statistically insignificant. In short, the impact of personal biases on the labor market indicators is modest at best, providing further reassurance of the reasonably high level of objectivity in the assessments contained in the GLS. It is because responses are only modestly affected by attitudes that the calibrated indices and the un-calibrated indices are so highly correlated.

\section{THE GLS LABOR MARKET INDICES}

The GLS indices in Table 5 capture several familiar patterns of cross-country differences in labor conditions, for instance between the United States and advanced Europe.

General Economic Situation: This index averaged the responses for questions 1.01-1.09 (Module 1a) regarding the level of the economy and the level of disparities in living standards within a country. The scores from developed countries were higher than those reported from developing countries, implying better economic performance and lower inequality. Still, the United States had a score of 3.762 that placed it in the lower half of countries, reflecting its high

level of inequality among advanced countries. By contrast, Japan ranked $9^{\text {th }}$ despite the prolonged recession that it experienced, which reflects the fact that the provision of public services such as education and healthcare remain widely accessible.

Role of World Bank and IMF: This measure took the mean response for questions 1.101.12 (Module 1b) about the extent of World Bank and IMF influence on domestic economic 
policy. Overall, the low scores indicate that respondents assessed the World Bank and the IMF to have favored the interests of business over that of workers. Several countries that received IMF rescue packages during recent financial crises, in particular Brazil, Mexico and South Korea, reported relatively high scores, consistent with the perception that these international organizations wield a large influence on domestic policies.

Labor Market Conditions: This index was the mean response for all the Module 2 questions, except question 2.10. The issues captured included how wages are set, the frequency of wage arrears, and the incidence of child labor and gender discrimination (both key targets of the ILO's fundamental conventions). Table 5 indicates that developed countries scored high on this index, with the United States being the major exception. Developing countries, including India and China, ranked among the bottom 10 countries.

Freedom of Association \& Collective Bargaining: This indicator averaged the responses from Module 3, excluding questions 3.01 and 3.08. Developing countries ranked low on labor union strength, while the Western European countries had much higher rankings. The United States and the United Kingdom had the lowest scores from the developed countries, ranking $20^{\text {th }}$ and $22^{\text {nd }}$ respectively.

Labor Disputes: This index averaged responses for Module 4 of the GLS. According to the index, the frequency of labor unrest and employer-employee conflict was lowest in countries such as Turkey, Singapore, and the United States. In contrast, France, Belgium and Italy had the highest scores, reflecting the strength of labor movements in these Western Europe countries.

Employment Regulations \& Working Conditions: This index gave the average of responses to Module 5, which deals with the extent of regulation of the labor market, such as the ease of hiring and firing. Low scores indicate a higher propensity towards employer discretion, 
whereas higher scores indicate a greater use of labor regulations or collective bargaining agreements to determine the terms of work contracts. The United States ranked $2^{\text {nd }}$ lowest among all countries, with a score virtually indistinguishable from China; this is indicative of the large scope and bargaining power of employers in the negotiation of contract terms with workers. The United Kingdom placed $10^{\text {th }}$ from the bottom. Labor regulation and collective bargaining were most influential in Western Europe, particularly in Scandinavian countries.

Employee Benefits: This index was the mean of responses in Module 6, covering pension schemes, sickness benefits and unemployment insurance. The trends and ranking mirrored closely those in the "Employment Regulations \& Working Conditions" index: Relatively low levels of benefits in developing countries, and higher levels in developed countries. Once again, the United States and the United Kingdom had significantly lower benefit levels compared to the rest of the developed world.

\section{Quantitative Estimates}

The GLS asked respondents to estimate the percentage of workers in the informal sector; the percentage who are labor union members; and the percentage covered by a collective bargaining agreement. These were coded on a 1-to-5 scale, with 1 representing $0-20 \%$ and 5 representing $80-100 \%$. There was greater variability in the responses to these questions than in many other questions, but even so, the estimates from the GLS were highly correlated with the percentage unionized, as well as the percentage employment in the unofficial economy reported in Botero et al. (2004), as illustrated in Figure 1.

$\%$ of workers in informal sector (Question 2.10): Developed countries yielded low estimates for this index, ranging between a response of 1 and 2 . The informal sector was large in developing countries, where the Philippines, Peru and India had scores near 4. 
$\%$ of workers who are labor union members (Question 3.01): Unionization rates were higher among the developed countries, with Denmark and Sweden approaching a score of 5. Several developing countries reported moderate levels of unionization, including Brazil, Mexico, Sri Lanka and India. The GLS accurately captured the low rates of union membership in France and the United States.

\% of labor force covered by a collective bargaining agreement (Question 3.08): The trends in collective bargaining coverage mirrored closely that of the labor union membership estimates. The main exceptions were several European countries, such as France, Italy and the Netherlands, where such agreements extend collective bargaining to workers broadly in the economy, so that the coverage rates exceed union membership rates.

\section{Do Workplace Institutions Form Systems?}

To see whether workplace institutions and practices come together as a bundle, we calculated a correlation matrix for all of the summary indices (Table 7). The correlation matrix suggests that workplace institutions broadly fit together into labor relations systems that can be classified as more or less favorable to workers. For example, looking at the third row, economies with more pro-worker "Labor Market Conditions" in terms of wage-setting institutions also tend to have greater "Freedom of Association \& Collective Bargaining" and higher levels of "Employee Benefits". They also have a low "\% informal sector", as well as high unionization and collective bargaining coverage rates.

The rightmost column in the table on "Personal Views \& Positions" shows how the mean across responses to the Module 7 questions are correlated with the other measures. Consistent with the regression coefficients in Table 6 , this indicator is only weakly correlated with the labor 
market indices. There is some evidence suggesting that countries where respondents were more leftwing tended to give lower marks in assessing the impact of the IMF \& World Bank.

In sum, the indices show that developed countries have a more pro-worker orientation, with more regulation of markets and greater union activity. The exceptions to this pattern are the United States, and to a lesser extent the United Kingdom, where labor unions are systematically weaker and labor markets are subject to less regulation than in the rest of the OECD.

\section{COMPARISON WITH OTHER MEASURES}

To see how the cross-country variation in labor market institutions and regulations in the GLS compares to the picture from other sources, we have gathered measures of labor conditions from: the Global Competitiveness Report survey of business executives; the Botero et al. (2004) measures on formal labor regulations; and the Fraser Institute's Economic Freedom around the World index. We proceed to discuss the correlation between these and the GLS measures.

\section{Global Competitiveness Report (GCR)}

The World Economic Forum's Global Competitiveness Report offers the best comparison with the GLS, since we adopted the same seven-point scale and question format from the GCR, while adapting some questions for the GLS to facilitate direct comparisons. The GCR asks managers about economic conditions in their country of operation, which should produce responses favorable to employer interests, in contrast to the pro-labor orientation of the GLS sample. Agreement between the two surveys on factual issues would thus go a long way towards validating both surveys. 
For our analysis, we matched 14 GLS questions with their counterparts in the 2004 GCR, as listed in Appendix Table 2. ${ }^{19}$ The correlation between the GCR and GLS country scores for these questions was statistically significant at the $1 \%$ level for all but two pairs, and even on those questions, there was a high correlation with closely related questions. ${ }^{20}$ The correlation coefficient ranged from a low of 0.44 to a high of 0.93 for the 12 significantly correlated pairs.

Similar results were obtained when we matched the GLS to the 2002 GCR. ${ }^{21}$ Excluding the questions pertaining to the World Bank and IMF, there were 11 question pairs, all of which were significantly correlated at least at the 5\% level. For the questions assessing the role of the World Bank and IMF, the correlation with the corresponding GLS questions was generally insignificant, except for one match: Greater World Bank and IMF influence on the domestic economy (GLS Question 1.10) was associated with lower ratings on the IMF's effectiveness in promoting high levels of employment and real income (2002 GCR Question 12.02B). On the whole, there is greater divergence between the business community and labor practitioners in their assessments on the impact of the World Bank and IMF than in their assessments of workplace practices.

\section{The Regulation of Labor: Botero et al. (2004) and the Doing Business Database}

We also compared the GLS measures with data on the regulation of labor from Botero et al. (2004), which is based on de jure government regulations and legal provisions, benchmarked

\footnotetext{
${ }^{19}$ The GCR scores for each question are based on a simple mean of the responses for a country. The GCR has a reverse coding of answering options, so that 7 is the most "pro-business" response and 1 the most "pro-labor". For consistency with the GLS, we transformed the GCR data by taking 8 minus the GCR scores.

${ }^{20}$ The insignificant correlations were for: GLS question 5.01 on the determination of contract terms for hiring fulltime workers and GCR question 7.02 on the hiring and firing of workers; and GLS question 2.14 on gender discrimination and GCR question 7.17 on how wages for women compare to that for men for similar work. But GCR question 7.02 displays a highly significant correlation with GLS question 5.10 on the ease of firing, while GCR question 7.16 on employment opportunities for women was significantly correlated with GLS question 2.14.

${ }^{21}$ The number of countries in the sample drops to 32 with the 2002 GCR, which does not include Cyprus.
} 
to 1997. The regulation data was aggregated into indices on: Employment laws, Collective relations laws, and Social security laws, with higher values indicating a greater extent of labor regulation. ${ }^{22}$ Again, we have natural comparisons because we designed the GLS to cover many of the same labor institutions. ${ }^{23}$

The top part of Table 8 records the correlation between the ten GLS indices and the Botero et al. (2004) labor regulation measures. The Employment laws index and the Social security laws index are significantly correlated with the GLS indices on workplace conditions from Modules 2-6 ("Labor Market Conditions" through "Employee Benefits"). In addition, the Social security laws index was highly correlated with the "General Economic Situation" index and negatively correlated with the "\% informal sector" variable. As for the Collective relations laws index, this had a significant correlation with the "Labor Disputes" module which covers the same set of issues, but was in general uncorrelated with most of the other GLS variables.

Although the GLS indices were consistent with the rankings by Botero et al. (2004), the correlations between the GLS and Botero et al. are much smaller than the correlations between the GLS and the GCR. We attribute part of this to the fact that Botero et al. measure de jure labor regulations, which will inevitably diverge from de facto workplace practices. ${ }^{24}$ In addition, there

\footnotetext{
${ }^{22}$ Each index comes from component indices, most coded on a 0-1 scale. For example, one of the sub-indices under the Collective relations index concerns the "Right to Unionization". This was coded 1 if the right to form a labor union was in the constitution, and coded 0 if the constitution did not refer to unions. Values of 0.33 or 0.67 were assigned for intermediate cases (for example, the constitution mentions unions, but not the right to form one.)

${ }^{23}$ Module 4 of the GLS on "Labor Disputes" parallels the Collective relations index, Module 5 on "Employment Regulations \& Working Conditions" parallels the component indices of their Employment laws index; Module 6 on "Employee Benefits" mirrors their Social security laws index.

${ }^{24}$ This de jure-de facto distinction is illustrated by the range of correlations found between some indices from Botero et al. and questions in the GLS. For example, the correlation between the "Right to Unionization" variable from Botero et al. and GLS question 3.03 on the protection of the right to form a union was a mere 0.02. By contrast, the Botero et al. dummy variable for whether the social security system protected against the risk of unemployment had a correlation of 0.77 with GLS question 6.06 on the extent to which unemployment benefits were determined by regulations or collective bargaining as opposed to by employers.
} 
are differences in the component questions that underlie the two measures. ${ }^{25}$ Table 8 also gives the correlations between the GLS and Botero et al. estimates of "\% informal sector" and "\% labor union" that are graphed in Figure 1. The insignificant correlation between the "\% collective bargaining" index and the "Right to Collective Bargaining" dummy variable from Botero et al. likely stems once again from the distinction between the de jure constitutional right and the actual de facto extension of collective bargaining agreements.

The World Bank's Doing Business database, set up to update measures of formal regulation per Botero et al. (2004), offers a further comparison between de jure and de facto labor practices. The most recent edition of the Doing Business database contains a Rigidity of Employment Index benchmarked to January 2004, based on laws relating to the hiring and firing workers, and the rigidity of work hours. The row labeled "Doing Business" in Table 8 shows that this index was uncorrelated with any GLS measures of workplace conditions, including the GLS index on "Employment Regulations and Working Conditions". Again, this is a warning that legal regulations need not tell what actually happens in work places.

\section{Economic Freedom of the World (EFW)}

Our third cross-check comes from the index of labor regulation compiled in the 2004 Economic Freedom of the World Report, sponsored by the Fraser Institute, whose assessment of labor regulations is predicated on a position advocating laissez-faire institutions. The labor regulation index (Area 5B of the EFW, Gwartney and Lawson, 2004) consisted of five components: Impact of the minimum wage; Hiring and firing practices; Labor force share with wages set by centralized bargaining; Unemployment insurance; and Use of conscripts. The first four components incorporated information from recent editions (2001-2003) of the GCR, but we

\footnotetext{
${ }^{25}$ For example, the GLS asked (in question 6.03) about the prevalence of private pension programs, an area that is not covered by Botero et al.
} 
still treated the overall index as a valid assessment of the extent of labor regulation. As shown in the final row of Table 8, the EFW index was negatively correlated with most of the GLS indices of workplace conditions, as it should since the EFW codes pro-labor regulation as undesirable.

In sum, our cross-checks show that most sources are in broad agreement on the approximate ranking of countries regarding the degree to which their institutions favor labor versus business interests. The union leaders and activists on the GLS, the business executives on the GCR, and the conservative analysts for the Fraser Institute's economic freedom measures are in broad agreement about actual practices, though they presumably differ greatly in the value judgments that they attach to the practices.

\section{CORRELATION WITH ECONOMIC OUTCOMES}

Is the GLS ranking of countries by labor practices connected with broad economic conditions? As a first step towards answering this question, we sorted the 33 countries into quartiles based on the mean real GDP per capita from 2001-2003, as reported in the World Development Indicators (WDI). Table 9 shows one dominant fact from this analysis: Countries that are more developed tend to have more pro-labor workplace institutions and practices. The mean (and median) scores on "Labor Market Conditions" through "Employee Benefits" (based on Parts 2-6 of the GLS), as well as "\% labor union" and "\% collective bargaining" are higher as we move towards higher income quartiles, although there is some tapering off between the $3^{\text {rd }}$ and $4^{\text {th }}$ highest quartiles. In addition, richer countries had higher scores on the "General Economic Situation” index, as well as a smaller “\% informal sector". These patterns are very robust to an alternative sorting into income brackets, as given by the World Bank's classification of Developing, High-income non-OECD and OECD countries. 
This systematic variation of workplace conditions with income levels is further confirmed by Table10, which displays the results from a series of least-squares regressions of various economic outcome variables on each GLS index in turn. The bivariate regressions on the 2001-2003 mean level of real GDP per capita point once again to more pro-labor conditions been associated with higher country income levels. ${ }^{26}$

Column 2 of Table 10 examines the relation between the indices of labor institutions and inequality of incomes, as measured by the Gini coefficients from Deininger and Squire (1996), restricting the data to points they label as "high quality". The consistently negative coefficients on the various labor market indicators, as well as on "\% labor union" and "\% collective bargaining" suggest that pro-labor institutions redistribute income towards employees.

The next column of Table 10 shows that the growth rate of real GDP per capita (computed as an average over a three-year period, 2000-2003) is unrelated to labor practices. With regards to the unemployment rate (also taken from the WDI), ${ }^{27}$ the "Freedom of Association \& Collective Bargaining”, "Labor Disputes" and "Employment Regulations \& Working Conditions" indices had positive coefficients that were significant at the $10 \%$ level, suggesting a moderate correlation between pro-labor institutions and unemployment. ${ }^{28}$ Finally, we explored the possible causal links in these relations, using a set of legal origin dummies as instrumental variables for the GLS indices. ${ }^{29}$ In the IV estimates labor institutions remained correlated to GDP per capita and inequality, but not to the growth rate and the unemployment rate (regressions not shown).

\footnotetext{
${ }^{26}$ We obtained similar results with a 5-year log average of real GDP per capita as dependent variable.

27 The unemployment rate for 2001 was used, as it was the most recent year in the WDI for which data was available for almost all countries in our sample (31 out of 33 countries).

${ }^{28}$ However, these coefficients are not significant if we remove the level of real GDP per capita from the regression.

${ }^{29}$ The instrumental variables were dummies for British, French, German, Scandinavian and socialist legal origin.
} 


\section{CONCLUSION}

This study has demonstrated the feasibility of asking labor practitioners and experts over the Internet about actual labor practices in their country. The GLS obtained responses from nearly 1,600 respondents in a large number of countries. The responses tended to agree on practices within country while showing considerable cross-country variation. Based on the survey, we constructed labor market indices for 33 countries and found that our measures correlated well with the estimates of labor market conditions and regulations from the comparable GCR and Fraser EFW measures of labor markets around the world. The data suggests further that workplace conditions that offer workers more safeguards and benefits tend to be associated with countries with higher levels of income per capita and less inequality, are unrelated to growth rates, and weakly positively correlated with unemployment rates.

The major weakness of the 2004 survey was the small sample of respondents from many developing countries. In part, this was because e-mail lists included only a few practitioners in those countries, and because weak Internet connections might have made it difficult for them to respond. This suggests the need for expanding the reach of the survey by obtaining assistance from country-based organizations to supplement the Internet sample through non-Internet-based surveying, for example by inviting country practitioners and experts to fill out the surveys as part of a conference. Translating the survey into more languages and having it available on a widely used web site rather than as a stand-alone URL might also have increased the responses. In addition, the survey would have benefited from more responses from personnel and labor relations practitioners from the business community. Despite these shortcomings, the diagnostics 
and the crosschecks with other data sources showed that the GLS captured useful information for comparing actual labor market practices across countries. 


\section{REFERENCES}

Baccaro, Lucio, Jean-Michel Bonvin, Jean-Pierre Laviec, Patricia O’Donovan, Gilbert Ritschard, and Djamel A. Zighed, (2003), "Social Dialogue Regimes: An Investigation in the Structural Determinants and Socioeconomic Outcomes of Negotiated Regulation," research proposal.

Besley, Timothy, and Robin Burgess, (2004), "Can Labor Regulation Hinder Economic Performance? Evidence from India,” Quarterly Journal of Economics, 118: 91-134.

Bohning, W.R., (2003), “Gaps in Basic Workers' Rights: Measuring International Adherence To and Implementation of the Organization's Values with Public ILO Data," ILO International Labor Office Working Paper.

Botero, Juan, Simeon Djankov, Rafael La Porta, Florencio Lopez-de-Silanes, and Andrei Shleifer, (2004), “The Regulation of Labor," Quarterly Journal of Economics, 119: 13391382.

Deininger, Klaus and Lyn Squire, (1996), “A New Data Set Measuring Income Inequality”, World Bank Economic Review 10: 565-91.

Forteza, Alvaro, and Martin Rama, (2002), "Labor Market 'Rigidity' and the Success of Economic Reforms across more than One Hundred Countries," World Bank, mimeo.

Freeman, Richard B., (2005), "Labour Market Institutions Without Blinders: The Debate over Flexibility and Labour Market Performance,” NBER Working Paper No. 11286.

Gwartney, James, and Robert Lawson, (2004), Economic Freedom of the World: 2004 Annual Report, Vancouver: The Fraser Institute. Data from: www.freetheworld.com.

James, Lawrence, Robert Demaree, and Gerrit Wolf, (1984), "Estimating Within-Group Interrater Reliability With and Without Response Bias," Journal of Applied Psychology, 69: 85-98.

Organization for Economic Cooperation and Development (OECD), (1994), OECD Jobs Study, Evidence and Explanations, Part I: Labor Market Trends and Underlying Forces of Change. Paris: OECD.

Shrout, P.E., and J.L. Fleiss, (1979), "Intraclass correlations: Uses in Assessing Rater Reliability," Psychological Bulletin, 86: 420-428.

Verité, (2003), "Emerging Markets Research Project: Year-End Report," prepared for the California Public Employees Retirement System (CalPERS). 
Winer, B.J., D.R. Brown, and K.M. Michels, (1991), Statistical Principles in Experimental Design," $3^{\text {rd }}$ edition. New York: McGraw Hill.

World Bank, various years, World Development Indicators. Washington DC: World Bank. Online resource.

World Bank, (1995), World Development Report. Washington, DC: The World Bank.

World Bank, (2005), Doing Business: Benchmarking Business Regulations. Database at: http://rru.worldbank.org/DoingBusiness/

World Economic Forum, various years, The Global Competitiveness Report. Geneva: World Economic Forum. 
TABLE 1: Module Structure of the Global Labor Survey (GLS)

\begin{tabular}{|l|l|}
\hline \multicolumn{1}{|c|}{ Number and Name of Module } & Issues Covered \\
\hline 1. General Economic Situation & $\begin{array}{l}\text { Economic growth; Unemployment and poverty; } \\
\text { Influence of IMF and World Bank on country policies. }\end{array}$ \\
\hline $\begin{array}{l}\text { 2. } \text { The Labor Market } \\
\text { Wage-setting; Enforcement of minimum wage policies; } \\
\text { Wage arrears; Prevalence of child labor; Gender } \\
\text { discrimination. }\end{array}$ \\
\hline $\begin{array}{l}\text { 3. } \text { Freedom of Association \& } \\
\text { Labor Disputes }\end{array}$ & Legal and economic position of unions. \\
\hline $\begin{array}{l}\text { 5. } \text { Employment Regulations \& } \\
\text { Working Conditions }\end{array}$ & $\begin{array}{l}\text { Nature and frequency of industrial disputes; Institutions } \\
\text { for resolving labor conflicts. } \\
\text { contracts, work hours, hiring and firing decisions. }\end{array}$ \\
\hline $\begin{array}{l}\text { 6. } \text { Employee Benefits } \\
\text { 7. Concluding Questions }\end{array}$ & $\begin{array}{l}\text { Pension schemes; Sickness benefits; Unemployment } \\
\text { insurance. }\end{array}$ \\
\hline \hline
\end{tabular}




\section{TABLE 2: Response Counts by Country}

\begin{tabular}{|c|c|c|c|c|c|}
\hline Country & ISO code & Count & Country & ISO code & Count \\
\hline Argentina & ARG & 3 & Latvia & LVA & 2 \\
\hline Australia & AUS & 203 & Lebanon & LBN & 1 \\
\hline Austria & AUT & 4 & Libya & LBY & 1 \\
\hline Barbados & BRB & 3 & Malaysia & MYS & 5 \\
\hline Belgium & BEL & 9 & Mexico & MEX & 7 \\
\hline Benin & BEN & 1 & Nepal & NPL & 1 \\
\hline Bhutan & BTN & 1 & Netherlands & NLD & 14 \\
\hline Botswana & BWA & 1 & New Zealand & NZL & 40 \\
\hline Brazil & BRA & 32 & Nigeria & NGA & 3 \\
\hline Bulgaria & BGR & 1 & Norway & NOR & 32 \\
\hline Burkina Faso & BFA & 1 & Oman & OMN & 1 \\
\hline Canada & CAN & 457 & Pakistan & PAK & 2 \\
\hline Cape Verde & CPV & 1 & Palestinian Territory & PSE & 1 \\
\hline Chile & $\mathrm{CHL}$ & 3 & Peru & PER & 14 \\
\hline China & $\mathrm{CHN}$ & 7 & Philippines & $\mathrm{PHL}$ & 8 \\
\hline Cyprus & CYP & 11 & Portugal & PRT & 2 \\
\hline Czech Republic & CZE & 1 & Puerto Rico & PRI & 1 \\
\hline Denmark & DNK & 8 & Romania & ROU & 2 \\
\hline Djibouti & DJI & 1 & Rwanda & RWA & 2 \\
\hline Dominican Republic & DOM & 1 & Sierra Leone & SLE & 1 \\
\hline Estonia & EST & 1 & Singapore & SGP & 5 \\
\hline Fiji & FJI & 1 & Slovenia & SVN & 1 \\
\hline Finland & FIN & 4 & South Africa & $\mathrm{ZAF}$ & 10 \\
\hline France & FRA & 7 & Spain & ESP & 3 \\
\hline Germany & DEU & 11 & Sri Lanka & LKA & 5 \\
\hline Ghana & GHA & 1 & Sweden & SWE & 13 \\
\hline Greece & GRC & 3 & Switzerland & $\mathrm{CHE}$ & 4 \\
\hline Haiti & $\mathrm{HTI}$ & 1 & Taiwan & TWN & 8 \\
\hline Hong Kong & $H K G$ & 3 & Thailand & THA & 2 \\
\hline Hungary & HUN & 2 & Trinidad \& Tobago & TTO & 1 \\
\hline India & IND & 15 & Turkey & TUR & 4 \\
\hline Indonesia & IDN & 3 & United Kingdom & GBR & 139 \\
\hline Ireland & IRL & 8 & United States & USA & 400 \\
\hline Israel & ISR & 13 & United States Minor & UMI & 1 \\
\hline Italy & ITA & 6 & Outlying Islands & UMI & 1 \\
\hline Jamaica & JAM & 1 & Venezuela & VEN & 2 \\
\hline Japan & JPN & 6 & Vietnam & YNM & 1 \\
\hline Kenya & KEN & 1 & Yugoslavia & YUG & 1 \\
\hline Korea, South & KOR & 5 & Zimbabwe & ZWE & 1 \\
\hline
\end{tabular}

33 countries / territories with at least 4 respondents: Australia, Austria, Belgium, Brazil, Canada, China, Cyprus, Denmark, Finland, France, Germany, India, Ireland, Israel, Italy, Japan, Korea (South), Malaysia, Mexico, the Netherlands, New Zealand, Norway, Peru, the Philippines, Singapore, South Africa, Sri Lanka, Sweden, Switzerland, Taiwan, Turkey, the United Kingdom, the United States. 


\section{TABLE 3: Summary of Respondent Characteristics}

Sample: All countries

Panel A: Years of experience in country's labor affairs (Question 0.02)

\begin{tabular}{l|c|c}
\hline \hline & Counts & Percent (\%) \\
\hline \hline Less than 1 year & 44 & $2.8 \%$ \\
1 to 5 years & 247 & $15.6 \%$ \\
5 to 10 years & 247 & $15.6 \%$ \\
More than 10 years & 1039 & $65.7 \%$ \\
\hline \hline Total & 1582 & $99.7 \%$ \\
\hline \hline
\end{tabular}

Notes: Total does not sum to $100 \%$ because of 5 observations left blank by respondents. Percentages are similar when restricted to the 33 countries with 4 or more respondents.

Panel B: Background of survey respondents (Question 0.03)

\begin{tabular}{l||c|c}
\hline \hline & Counts & Percent (\%) \\
\hline \hline Academic & 290 & $18.3 \%$ \\
Corporate official & 35 & $2.2 \%$ \\
Government official & 69 & $4.4 \%$ \\
Independent lawyer / arbitrator & 28 & $1.8 \%$ \\
Journalist / Reporter & 20 & $1.3 \%$ \\
Labor activist & 465 & $29.4 \%$ \\
Labor union official & 496 & $31.4 \%$ \\
Other & 135 & $8.5 \%$ \\
\hline \hline Total & 1538 & $97.2 \%$ \\
\hline \hline
\end{tabular}

Notes: Total does not sum to $100 \%$ because of 44 observations left blank by respondents. Percentages are similar when restricted to the 33 countries with 4 or more respondents. 


\section{TABLE 3 (continued): Summary of Respondent Characteristics}

Sample: All countries

Panel C: Responses on Personal Views and Positions

\begin{tabular}{c|c|c|c}
\hline \hline Survey question & N & Mean & Std Dev \\
\hline \hline $\begin{array}{l}\text { 7.01: Political stance (right-wing } \\
\text { versus left-wing) }\end{array}$ & 1539 & 5.650 & 1.264 \\
$\begin{array}{c}\text { 7.02: Proper role of government in } \\
\text { economic policy-making }\end{array}$ & 1552 & 6.039 & 1.218 \\
$\begin{array}{l}\text { 7.03: Should workers or employers/the } \\
\text { state bear most responsibility for } \\
\text { employment and living standards? }\end{array}$ & 1550 & 5.165 & 1.868 \\
$\begin{array}{l}\text { 7.04: Need for global labor standards in } \\
\text { international trade agreements }\end{array}$ & 1558 & 6.415 & 1.339 \\
\hline \hline
\end{tabular}

Notes: Responses were on a scale of 1 to 7 , with 1 corresponding to a position most favorable towards private businesses and employers, and 7 corresponding to a position most favorably disposed towards workers' interests. 


\section{TABLE 4: Within-Country Reliability and Agreement of Survey Responses}

Sample: Countries with at least 4 respondents (33 countries, unless otherwise stated)

Panel A: James, Demaree and Wolf $r_{W G}$ Statistic

\begin{tabular}{l|c|c|c|c}
\hline \hline Agreement: $\mathbf{r}_{\text {WG }}$ & Mean & Min & Max & $\mathbf{r}_{\mathbf{W G}}<\mathbf{0 . 7}$ \\
\hline \hline Module 1a, qn 1.01-1.09 & 0.93 & 0.65 & 0.98 & Taiwan \\
Module 1b, qn 1.10-1.12 & 0.85 & 0.64 & 0.99 & Denmark; Norway \\
Module 2 (excl. qn 2.10) & 0.92 & 0.36 & 0.98 & Taiwan \\
Module 3 (excl. qn 3.01, 3.08) & 0.91 & 0.68 & 0.99 & China \\
Module 4 & 0.92 & 0.76 & 0.97 & --- \\
Module 5 & 0.90 & 0.30 & 0.98 & Taiwan \\
Module 6 & 0.88 & 0.41 & 0.98 & Taiwan \\
Module 7 & 0.84 & 0.65 & 0.97 & Brazil ; India \\
\hline \hline
\end{tabular}

Notes: The multiple-item scale $r_{\mathrm{WG}}$ statistic was computed; this captures the extent of agreement among the respondents from each country for each module of questions. The critical value of 0.7 for this statistic is regarded as a minimum threshold level of inter-respondent agreement. The sample of countries shrinks to 32 in the row for questions 1.10-1.12 only because of omissions in the responses for Finland. The min, max and mean are computed across countries.

Panel B: Intraclass Correlation Coefficient (ICC) and Spearman-Brown prediction formula (SB)

\begin{tabular}{|c|c|c|c|c|c|c|}
\hline & \multicolumn{3}{|c|}{ ICC } & \multicolumn{3}{|c|}{ SB } \\
\hline & Mean & Min & $\operatorname{Max}$ & Mean & Min & $\operatorname{Max}$ \\
\hline Module 1a, qn 1.01-1.09 & 0.38 & 0.16 & 0.54 & 0.95 & 0.88 & 0.98 \\
\hline Module 1b, qn 1.10-1.12 & 0.14 & 0.11 & 0.17 & 0.83 & 0.79 & 0.86 \\
\hline Module 2 (excl. qn 2.10) & 0.15 & 0.06 & 0.27 & 0.83 & 0.69 & 0.93 \\
\hline Module 3 (excl. qn 3.01, 3.08) & 0.27 & 0.07 & 0.57 & 0.90 & 0.75 & 0.98 \\
\hline Module 4 & 0.22 & 0.13 & 0.41 & 0.90 & 0.84 & 0.96 \\
\hline Module 5 & 0.22 & 0.07 & 0.43 & 0.89 & 0.75 & 0.97 \\
\hline Module 6 & 0.26 & 0.13 & 0.54 & 0.91 & 0.83 & 0.98 \\
\hline Module 7 & 0.09 & 0.02 & 0.19 & 0.70 & 0.46 & 0.90 \\
\hline
\end{tabular}

Notes: ICC for qn $2.10=0.28$; for qn $3.01=0.58$; for qn $3.08=0.59$. SB for qn $2.10=0.93$; for qn $3.01=0.98$; for qn $3.08=0.98$. The min, max and mean are computed across questions in each module. 


\section{TABLE 5: Indices of Labor Market and Workplace Conditions}

Module 1a (qn 1.01-1.09 only) General Economic Situation

\begin{tabular}{ll|c|c}
\hline \hline & Country & Mean & Std Dev \\
\hline \hline 1 & Norway & 5.809 & 0.128 \\
2 & Sweden & 5.614 & 0.103 \\
3 & Finland & 5.532 & 0.146 \\
4 & Denmark & 5.444 & 0.117 \\
5 & Netherlands & 5.174 & 0.123 \\
6 & Switzerland & 5.173 & 0.138 \\
7 & Cyprus & 5.079 & 0.136 \\
8 & New Zealand & 5.040 & 0.117 \\
9 & Japan & 4.958 & 0.156 \\
10 & Belgium & 4.887 & 0.150 \\
11 & Taiwan * & 4.854 & 0.148 \\
12 & Ireland & 4.824 & 0.130 \\
13 & Germany & 4.802 & 0.176 \\
14 & Canada & 4.660 & 0.108 \\
15 & Austria & 4.643 & 0.154 \\
16 & Australia & 4.634 & 0.112 \\
17 & United Kingdom & 4.628 & 0.112 \\
18 & Malaysia & 4.625 & 0.131 \\
19 & Singapore & 4.553 & 0.133 \\
20 & France & 4.433 & 0.122 \\
21 & Israel & 4.222 & 0.157 \\
22 & Italy & 3.842 & 0.167 \\
23 & United States & 3.762 & 0.111 \\
24 & Korea, South & 3.723 & 0.123 \\
25 & China & 3.554 & 0.124 \\
26 & India & 2.884 & 0.119 \\
27 & Sri Lanka & 2.851 & 0.133 \\
28 & Mexico & 2.682 & 0.150 \\
29 & Brazil & 2.646 & 0.149 \\
30 & South Africa & 2.609 & 0.152 \\
31 & Turkey & 2.547 & 0.166 \\
32 & Philippines & 2.406 & 0.129 \\
33 & Peru & 2.255 & 0.137 \\
\hline \hline & & & \\
\hline
\end{tabular}

Module 1b (qn 1.10-1.12 only) Role of World Bank \& IMF

\begin{tabular}{ll|c|c}
\hline \hline & Country & Mean & Std Dev \\
\hline 1 & Cyprus & 4.123 & 0.136 \\
2 & Peru & 3.919 & 0.195 \\
3 & Korea, South & 3.831 & 0.110 \\
4 & Sri Lanka & 3.824 & 0.178 \\
5 & Finland & 3.815 & 0.204 \\
6 & Mexico & 3.506 & 0.152 \\
7 & Israel & 3.487 & 0.148 \\
8 & South Africa & 3.456 & 0.139 \\
9 & Brazil & 3.452 & 0.141 \\
10 & Japan & 3.384 & 0.176 \\
11 & Turkey & 3.383 & 0.190 \\
12 & India & 3.341 & 0.109 \\
13 & Italy & 3.228 & 0.177 \\
14 & Australia & 3.193 & 0.133 \\
15 & France & 3.168 & 0.099 \\
16 & Norway * & 3.124 & 0.148 \\
17 & United Kingdom & 3.117 & 0.120 \\
18 & Sweden & 3.097 & 0.127 \\
19 & Malaysia & 3.075 & 0.100 \\
20 & Belgium & 3.061 & 0.137 \\
21 & Canada & 3.042 & 0.115 \\
22 & Netherlands & 3.004 & 0.116 \\
23 & Taiwan & 2.981 & 0.171 \\
24 & New Zealand & 2.955 & 0.122 \\
25 & Philippines & 2.945 & 0.078 \\
26 & Ireland & 2.820 & 0.136 \\
27 & Austria & 2.808 & 0.182 \\
28 & United States & 2.804 & 0.122 \\
29 & Singapore & 2.802 & 0.125 \\
30 & Denmark* & 2.643 & 0.130 \\
31 & China & 2.575 & 0.132 \\
32 & Germany & 2.448 & 0.169 \\
33 & Switzerland & 1.631 & 0.174 \\
\hline \hline & & & \\
\hline
\end{tabular}

Notes: Indices range from 1 to 7 , with 1 corresponding to conditions most favorable towards businesses and employers, and 7 corresponding to conditions most favorable towards workers. A * denotes those countries for which the $r_{w g}$ statistic was less than 0.7 for the relevant subset of questions. Details of the calibration procedure are in Section 3. The "Std Dev" column lists an upper bound of the standard deviation for the reported mean, taking into account possible covariances between variables. 


\section{TABLE 5 (continued): Indices of Labor Market and Workplace Conditions}

Module 2 (excl qn 2.10)

Labor Market Conditions

\begin{tabular}{ll|c|c}
\hline \hline & Country & Mean & Std Dev \\
\hline \hline 1 & Finland & 5.714 & 0.187 \\
2 & Netherlands & 5.378 & 0.169 \\
3 & Sweden & 5.345 & 0.129 \\
4 & Norway & 5.207 & 0.166 \\
5 & Belgium & 5.099 & 0.214 \\
6 & Germany & 5.024 & 0.218 \\
7 & Austria & 5.001 & 0.195 \\
8 & Denmark & 4.952 & 0.151 \\
9 & France & 4.855 & 0.177 \\
10 & Japan & 4.690 & 0.169 \\
11 & Singapore & 4.670 & 0.176 \\
12 & Italy & 4.655 & 0.201 \\
13 & New Zealand & 4.653 & 0.142 \\
14 & Australia & 4.558 & 0.146 \\
15 & Canada & 4.497 & 0.138 \\
16 & United Kingdom & 4.441 & 0.145 \\
17 & Cyprus & 4.429 & 0.179 \\
18 & South Africa & 4.359 & 0.197 \\
19 & Ireland & 4.261 & 0.169 \\
20 & Israel & 4.241 & 0.202 \\
21 & Switzerland & 4.241 & 0.194 \\
22 & Malaysia & 4.227 & 0.153 \\
23 & Korea, South & 4.138 & 0.129 \\
24 & United States & 4.061 & 0.150 \\
25 & Taiwan * & 3.886 & 0.154 \\
26 & Philippines & 3.837 & 0.175 \\
27 & China & 3.823 & 0.123 \\
28 & India & 3.788 & 0.153 \\
29 & Brazil & 3.581 & 0.178 \\
30 & Sri Lanka & 3.568 & 0.168 \\
31 & Turkey & 3.412 & 0.198 \\
32 & Mexico & 3.153 & 0.185 \\
33 & Peru & 2.773 & 0.166 \\
\hline \hline & & & \\
\hline
\end{tabular}

Module 3 (excl qn 3.01 \& 3.08)

Freedom of Association \&

Collective Bargaining

\begin{tabular}{ll|c|c}
\hline \hline & Country & Mean & Std Dev \\
\hline \hline 1 & Finland & 6.005 & 0.157 \\
2 & Germany & 5.884 & 0.194 \\
3 & Netherlands & 5.810 & 0.153 \\
4 & Belgium & 5.699 & 0.181 \\
5 & Sweden & 5.676 & 0.123 \\
6 & Norway & 5.504 & 0.152 \\
7 & Denmark & 5.497 & 0.139 \\
8 & France & 5.260 & 0.170 \\
9 & Switzerland & 5.251 & 0.153 \\
10 & Austria & 5.237 & 0.202 \\
11 & Japan & 5.189 & 0.174 \\
12 & Italy & 5.113 & 0.212 \\
13 & South Africa & 5.053 & 0.175 \\
14 & Israel & 5.001 & 0.184 \\
15 & Canada & 4.867 & 0.139 \\
16 & New Zealand & 4.800 & 0.143 \\
17 & Australia & 4.717 & 0.141 \\
18 & Ireland & 4.640 & 0.175 \\
19 & Korea, South & 4.472 & 0.119 \\
20 & United Kingdom & 4.461 & 0.140 \\
21 & Cyprus & 4.220 & 0.156 \\
22 & United States & 4.208 & 0.148 \\
23 & Brazil & 4.079 & 0.148 \\
24 & Philippines & 4.067 & 0.149 \\
25 & Malaysia & 3.903 & 0.141 \\
26 & Peru & 3.877 & 0.151 \\
27 & India & 3.831 & 0.125 \\
28 & Singapore & 3.796 & 0.147 \\
29 & Taiwan & 3.496 & 0.150 \\
30 & Sri Lanka & 3.486 & 0.184 \\
31 & Turkey & 3.378 & 0.186 \\
32 & Mexico & 3.239 & 0.174 \\
33 & China * & 3.093 & 0.122 \\
\hline \hline & & & \\
\hline
\end{tabular}

Notes: Indices range from 1 to 7 , with 1 corresponding to conditions most favorable towards businesses and employers, and 7 corresponding to conditions most favorable towards workers. A * denotes those countries for which the $r_{\mathrm{wg}}$ statistic was less than 0.7 for the relevant subset of questions. Details of the calibration procedure are in Section 3. The "Std Dev" column lists an upper bound of the standard deviation for the reported mean, taking into account possible covariances between variables. 
TABLE 5 (continued): Indices of Labor Market and Workplace Conditions

Module 4

Labor Disputes

\begin{tabular}{ll|c|c}
\hline \hline & Country & Mean & Std Dev \\
\hline \hline 1 & France & 5.128 & 0.138 \\
2 & Belgium & 5.095 & 0.171 \\
3 & Italy & 5.075 & 0.192 \\
4 & Finland & 4.664 & 0.203 \\
5 & Denmark & 4.633 & 0.136 \\
6 & Netherlands & 4.561 & 0.149 \\
7 & Austria & 4.558 & 0.201 \\
8 & Norway & 4.535 & 0.145 \\
9 & South Africa & 4.381 & 0.167 \\
10 & Ireland & 4.363 & 0.151 \\
11 & Israel & 4.355 & 0.150 \\
12 & Sweden & 4.293 & 0.128 \\
13 & Cyprus & 4.202 & 0.171 \\
14 & Peru & 4.161 & 0.162 \\
15 & Korea, South & 4.123 & 0.133 \\
16 & Philippines & 4.026 & 0.160 \\
17 & Switzerland & 4.008 & 0.155 \\
18 & Australia & 3.996 & 0.128 \\
19 & Japan & 3.978 & 0.165 \\
20 & India & 3.871 & 0.147 \\
21 & New Zealand & 3.848 & 0.129 \\
22 & United Kingdom & 3.811 & 0.123 \\
23 & Canada & 3.805 & 0.118 \\
24 & Brazil & 3.719 & 0.191 \\
25 & Germany & 3.697 & 0.181 \\
26 & China & 3.617 & 0.133 \\
27 & Malaysia & 3.612 & 0.150 \\
28 & Mexico & 3.481 & 0.157 \\
29 & Sri Lanka & 3.458 & 0.161 \\
30 & United States & 3.294 & 0.124 \\
31 & Taiwan & 3.113 & 0.149 \\
32 & Singapore & 3.071 & 0.190 \\
33 & Turkey & 2.715 & 0.165 \\
\hline \hline & & & \\
\hline
\end{tabular}

Module 5

Employment Regulations \&

Working Conditions

\begin{tabular}{ll|c|c}
\hline \hline & Country & Mean & Std Dev \\
\hline 1 & Sweden & 6.102 & 0.157 \\
2 & Belgium & 6.100 & 0.261 \\
3 & Finland & 6.019 & 0.198 \\
4 & Netherlands & 6.014 & 0.206 \\
5 & Italy & 5.933 & 0.226 \\
6 & Germany & 5.914 & 0.257 \\
7 & Norway & 5.888 & 0.199 \\
8 & France & 5.882 & 0.249 \\
9 & Cyprus & 5.730 & 0.158 \\
10 & Denmark & 5.684 & 0.211 \\
11 & Austria & 5.533 & 0.232 \\
12 & Israel & 5.298 & 0.241 \\
13 & Ireland & 5.273 & 0.213 \\
14 & South Africa & 5.258 & 0.237 \\
15 & Australia & 5.145 & 0.199 \\
16 & New Zealand & 5.142 & 0.173 \\
17 & Canada & 5.107 & 0.182 \\
18 & Japan & 4.940 & 0.196 \\
19 & India & 4.937 & 0.184 \\
20 & Singapore & 4.851 & 0.215 \\
21 & Brazil & 4.816 & 0.194 \\
22 & Switzerland & 4.719 & 0.243 \\
23 & Korea, South & 4.653 & 0.142 \\
24 & United Kingdom & 4.640 & 0.194 \\
25 & Malaysia & 4.605 & 0.165 \\
26 & Philippines & 4.579 & 0.194 \\
27 & Turkey & 4.428 & 0.277 \\
28 & Sri Lanka & 4.228 & 0.210 \\
29 & Peru & 4.021 & 0.194 \\
30 & Mexico & 4.011 & 0.229 \\
31 & China & 4.008 & 0.133 \\
32 & United States & 3.999 & 0.192 \\
33 & Taiwan * & 3.856 & 0.159 \\
\hline \hline & & & \\
\hline
\end{tabular}

Notes: Indices range from 1 to 7 , with 1 corresponding to conditions most favorable towards businesses and employers, and 7 corresponding to conditions most favorable towards workers. A * denotes those countries for which the $r_{w g}$ statistic was less than 0.7 for the relevant subset of questions. Details of the calibration procedure are in Section 3. The "Std Dev" column lists an upper bound of the standard deviation for the reported mean, taking into account possible covariances between variables. 


\section{TABLE 5 (continued): Indices of Labor Market and Workplace Conditions}

Module 6

Employee Benefits

\begin{tabular}{ll|c|c}
\hline \hline & Country & Mean & Std Dev \\
\hline \hline 1 & Netherlands & 5.808 & 0.132 \\
2 & Sweden & 5.788 & 0.102 \\
3 & Norway & 5.613 & 0.146 \\
4 & Denmark & 5.557 & 0.124 \\
5 & Finland & 5.446 & 0.177 \\
6 & Switzerland & 5.377 & 0.178 \\
7 & Belgium & 5.177 & 0.191 \\
8 & Germany & 5.062 & 0.180 \\
9 & France & 5.021 & 0.170 \\
10 & Austria & 4.972 & 0.176 \\
11 & Israel & 4.900 & 0.168 \\
12 & Taiwan * & 4.892 & 0.150 \\
13 & Japan & 4.865 & 0.151 \\
14 & Cyprus & 4.843 & 0.177 \\
15 & New Zealand & 4.484 & 0.136 \\
16 & Italy & 4.383 & 0.184 \\
17 & Australia & 4.284 & 0.131 \\
18 & Canada & 4.272 & 0.126 \\
19 & Malaysia & 4.127 & 0.181 \\
20 & United Kingdom & 4.055 & 0.131 \\
21 & Ireland & 4.055 & 0.155 \\
22 & Korea, South & 3.716 & 0.134 \\
23 & Peru & 3.445 & 0.145 \\
24 & Brazil & 3.232 & 0.161 \\
25 & China & 3.179 & 0.114 \\
26 & Turkey & 3.103 & 0.161 \\
27 & India & 3.067 & 0.143 \\
28 & United States & 3.065 & 0.133 \\
29 & South Africa & 3.026 & 0.186 \\
30 & Philippines & 2.871 & 0.196 \\
31 & Mexico & 2.600 & 0.150 \\
32 & Singapore & 2.225 & 0.147 \\
33 & Sri Lanka & 2.224 & 0.172 \\
\hline \hline & & & \\
\hline
\end{tabular}

Question 2.10

$\%$ of workers in informal sector

\begin{tabular}{ll|c|c}
\hline \hline & Country & Mean & Std Dev \\
\hline \hline 1 & India * & 3.884 & 0.061 \\
2 & Philippines * & 3.767 & 0.073 \\
3 & Peru & 3.727 & 0.099 \\
4 & Sri Lanka & 3.376 & 0.047 \\
5 & Brazil & 3.001 & 0.102 \\
6 & Taiwan * & 2.947 & 0.061 \\
7 & Mexico & 2.887 & 0.048 \\
8 & Turkey * & 2.780 & 0.072 \\
9 & China * & 2.640 & 0.038 \\
10 & Korea, South * & 2.610 & 0.052 \\
11 & Switzerland * & 2.499 & 0.081 \\
12 & South Africa & 2.223 & 0.066 \\
13 & Canada * & 1.863 & 0.041 \\
14 & Ireland * & 1.845 & 0.045 \\
15 & Italy & 1.830 & 0.087 \\
16 & Austria & 1.753 & 0.077 \\
17 & Malaysia & 1.742 & 0.054 \\
18 & Singapore & 1.737 & 0.094 \\
19 & United States * & 1.722 & 0.040 \\
20 & Australia & 1.586 & 0.051 \\
21 & New Zealand & 1.579 & 0.052 \\
22 & United Kingdom & 1.484 & 0.045 \\
23 & Japan & 1.444 & 0.089 \\
24 & Sweden & 1.386 & 0.055 \\
25 & Denmark & 1.378 & 0.046 \\
26 & Cyprus & 1.266 & 0.091 \\
27 & Germany & 1.266 & 0.057 \\
28 & Norway & 1.266 & 0.052 \\
29 & Israel & 1.231 & 0.049 \\
30 & Netherlands & 1.231 & 0.043 \\
31 & Finland & 1.144 & 0.069 \\
32 & Belgium & 1.116 & 0.066 \\
33 & France & 1.102 & 0.038 \\
\hline \hline & & & \\
\hline
\end{tabular}

Notes: Indices range from 1 to 7 , with 1 corresponding to conditions most favorable towards businesses and employers, and 7 corresponding to conditions most favorable towards workers. For questions seeking a quantitative estimate, scores were coded from a 1 for an estimate of $0-20 \%$, to 5 for an estimate of $81-100 \%$. A $*$ denotes those countries for which the $r_{\mathrm{wg}}$ statistic was less than 0.7 for the relevant subset of questions. Details of the calibration procedure are in Section 3. The "Std Dev" column lists an upper bound of the standard deviation for the reported mean, taking into account possible covariances between variables. 
TABLE 5 (continued): Indices of Labor Market and Workplace Conditions

\begin{tabular}{|c|c|c|c|}
\hline & Country & Mean & Std Dev \\
\hline 1 & Sweden & 4.922 & 0.034 \\
\hline 2 & Denmark & 4.791 & 0.042 \\
\hline 3 & Finland & 4.344 & 0.061 \\
\hline 4 & Belgium & 3.681 & 0.038 \\
\hline 5 & Cyprus & 3.523 & 0.075 \\
\hline 6 & Norway & 3.306 & 0.040 \\
\hline 7 & China * & 3.096 & 0.043 \\
\hline 8 & Austria & 2.963 & 0.052 \\
\hline 9 & South Africa * & 2.740 & 0.045 \\
\hline 10 & Ireland & 2.553 & 0.051 \\
\hline 11 & Switzerland & 2.365 & 0.062 \\
\hline 12 & Israel & 2.348 & 0.040 \\
\hline 13 & Canada & 2.309 & 0.042 \\
\hline 14 & United Kingdom & 2.294 & 0.042 \\
\hline 15 & Australia & 2.253 & 0.042 \\
\hline 16 & Germany & 2.252 & 0.044 \\
\hline 17 & Italy & 2.223 & 0.057 \\
\hline 18 & Netherlands & 2.174 & 0.038 \\
\hline 19 & New Zealand & 2.151 & 0.043 \\
\hline 20 & India * & 1.947 & 0.054 \\
\hline 21 & Sri Lanka * & 1.936 & 0.066 \\
\hline 22 & Brazil * & 1.933 & 0.098 \\
\hline 23 & Mexico & 1.891 & 0.051 \\
\hline 24 & Taiwan & 1.863 & 0.051 \\
\hline 25 & Japan * & 1.791 & 0.054 \\
\hline 26 & Singapore & 1.697 & 0.067 \\
\hline 27 & United States & 1.394 & 0.042 \\
\hline 28 & Philippines & 1.296 & 0.045 \\
\hline 29 & Turkey & 1.251 & 0.054 \\
\hline 30 & France & 1.200 & 0.050 \\
\hline 31 & Peru & 1.150 & 0.067 \\
\hline 32 & Korea, South & 1.061 & 0.045 \\
\hline 33 & Malaysia & 1.054 & 0.059 \\
\hline
\end{tabular}

Question 3.08

$\%$ of labor force covered by a collective

bargaining agreement

\begin{tabular}{ll|c|c}
\hline \hline & Country & Mean & Std Dev \\
\hline 1 & Sweden & 4.983 & 0.047 \\
2 & Finland & 4.731 & 0.047 \\
3 & Belgium & 4.715 & 0.075 \\
4 & Austria & 4.413 & 0.086 \\
5 & Netherlands & 4.253 & 0.047 \\
6 & Denmark & 4.229 & 0.040 \\
7 & France & 4.114 & 0.077 \\
8 & Italy * & 3.816 & 0.085 \\
9 & Norway * & 3.755 & 0.056 \\
10 & Germany & 3.644 & 0.053 \\
11 & Switzerland * & 3.609 & 0.093 \\
12 & Cyprus & 3.505 & 0.055 \\
13 & Ireland * & 3.447 & 0.076 \\
14 & Australia * & 2.826 & 0.058 \\
15 & South Africa * & 2.706 & 0.071 \\
16 & Israel & 2.604 & 0.059 \\
17 & United Kingdom * & 2.368 & 0.061 \\
18 & Canada & 2.312 & 0.059 \\
19 & Brazil * & 2.154 & 0.063 \\
20 & New Zealand & 1.801 & 0.054 \\
21 & Mexico * & 1.746 & 0.052 \\
22 & India * & 1.735 & 0.049 \\
23 & Singapore * & 1.689 & 0.062 \\
24 & Japan & 1.486 & 0.068 \\
25 & China & 1.459 & 0.041 \\
26 & Sri Lanka & 1.445 & 0.103 \\
27 & United States & 1.390 & 0.065 \\
28 & Taiwan & 1.323 & 0.054 \\
29 & Philippines & 1.283 & 0.065 \\
30 & Turkey & 1.205 & 0.061 \\
31 & Peru & 1.086 & 0.089 \\
32 & Malaysia & 0.957 & 0.043 \\
33 & Korea, South & 0.867 & 0.054 \\
\hline \hline & & & \\
\hline
\end{tabular}

Notes: Indices range from 1 to 5, ranging from a 1 for an estimate of $0-20 \%$, to 5 for an estimate of $81-100 \%$. A $*$ denotes those countries for which the $r_{w g}$ statistic was less than 0.7 for the relevant subset of questions. Details of the calibration procedure are in Section 3. The "Std Dev" column lists an upper bound of the standard deviation for the reported mean, taking into account possible covariances between variables. 
TABLE 6: Estimated Effect of Respondent Orientation on their Perception of Labor Conditions in their Country

\begin{tabular}{|c|c|c|c|c|c|c|c|}
\hline & \multicolumn{7}{|c|}{ Coefficient (Standard Error) } \\
\hline & Module 1a & Module 1b & Module 2 & Module 3 & Module 4 & Module 5 & Module 6 \\
\hline & $\begin{array}{l}\text { General } \\
\text { Economic } \\
\text { Situation }\end{array}$ & $\begin{array}{l}\text { Role of IMF \& } \\
\text { World Bank }\end{array}$ & $\begin{array}{l}\text { Labor Market } \\
\text { Conditions }\end{array}$ & $\begin{array}{l}\text { Freedom of } \\
\text { Association \& } \\
\text { Collective } \\
\text { Bargaining }\end{array}$ & Labor Disputes & $\begin{array}{l}\text { Employment } \\
\text { Regulations \& } \\
\text { Working } \\
\text { Conditions }\end{array}$ & $\begin{array}{l}\text { Employee } \\
\text { Benefits }\end{array}$ \\
\hline $\begin{array}{l}\text { Respondent Orientation } \\
\text { 7.01: Political orientation } \\
\text { (right-wing vs left-wing) }\end{array}$ & $0.06(0.06)$ & $-0.03 * *(0.01)$ & $0.02(0.03)$ & $0.02(0.03)$ & $-0.01(0.01)$ & $-0.02(0.02)$ & $0.01(0.04)$ \\
\hline $\begin{array}{l}\text { 7.02: Role of government in } \\
\text { economic policy-making }\end{array}$ & $-0.03(0.04)$ & $0.01(0.01)$ & $-0.01(0.02)$ & $0.00(0.02)$ & $0.01(0.01)$ & $0.02(0.02)$ & $-0.01(0.03)$ \\
\hline $\begin{array}{l}\text { 7.03: State responsibility for } \\
\text { workers' living standards }\end{array}$ & $0.03 * * *(0.01)$ & $0.01(0.00)$ & $0.01(0.01)$ & $0.01(0.01)$ & $0.01(0.01)$ & $0.02(0.01)$ & $0.03(0.02)$ \\
\hline $\begin{array}{l}\text { 7.04: Labor clauses in trade } \\
\text { agreements }\end{array}$ & $-0.00(0.03)$ & $-0.02 *(0.01)$ & $0.00(0.01)$ & $0.01(0.02)$ & $-0.01(0.01)$ & $-0.02(0.02)$ & $-0.02(0.03)$ \\
\hline \multicolumn{8}{|l|}{ Occupation } \\
\hline Corporate official & $-0.03(0.23)$ & $0.09(0.10)$ & $0.05(0.09)$ & $0.06(0.13)$ & $0.22 * *(0.09)$ & $0.20(0.14)$ & $0.05(0.21)$ \\
\hline Government official & $-0.15(0.20)$ & $0.16^{* *}(0.06)$ & $-0.12(0.14)$ & $-0.09(0.12)$ & $0.10(0.08)$ & $0.02(0.14)$ & $-0.08(0.17)$ \\
\hline Independent lawyer / arbitrator & $-0.49(0.29)$ & $0.20 * *(0.08)$ & $-0.31(0.19)$ & $-0.18(0.13)$ & $0.01(0.07)$ & $-0.14(0.13)$ & $-0.20(0.19)$ \\
\hline Journalist / Reporter & $-0.18(0.18)$ & $0.02(0.06)$ & $-0.02(0.10)$ & $0.01(0.11)$ & $0.01(0.10)$ & $-0.02(0.13)$ & $-0.15(0.17)$ \\
\hline Labor activist & $0.03(0.12)$ & $-0.05(0.04)$ & $-0.03(0.07)$ & $-0.07(0.11)$ & $-0.12 *(0.06)$ & $-0.15(0.13)$ & $-0.18(0.15)$ \\
\hline Labor union official & $0.11(0.11)$ & $-0.04(0.04)$ & $0.00(0.07)$ & $-0.04(0.09)$ & $-0.09(0.05)$ & $-0.08(0.10)$ & $-0.09(0.12)$ \\
\hline Other & $-0.04(0.12)$ & $-0.03(0.04)$ & $-0.06(0.07)$ & $-0.09(0.10)$ & $-0.12 * *(0.06)$ & $-0.16(0.12)$ & $-0.22(0.14)$ \\
\hline $\begin{array}{l}\text { Occupation = NA } \\
\text { Omitted Group = Academic }\end{array}$ & $-0.07(0.15)$ & $0.04(0.05)$ & $-0.01(0.09)$ & $-0.02(0.10)$ & $0.02(0.08)$ & $0.04(0.10)$ & $-0.08(0.16)$ \\
\hline $\begin{array}{l}\text { Dummy = } 1 \text { if NOT } \\
\text { Labourstart correspondent }\end{array}$ & $-0.09(0.07)$ & $-0.05 * *(0.02)$ & $-0.04(0.03)$ & $-0.02(0.05)$ & $-0.07 *(0.04)$ & $-0.09(0.07)$ & $-0.12(0.08)$ \\
\hline R-squared & 0.05 & 0.10 & 0.03 & 0.02 & 0.05 & 0.03 & 0.02 \\
\hline
\end{tabular}

Notes: $\mathrm{N}=1415$ for all regressions. Additional controls include dummy variables for years of experience, and a dummy for not replying to the Labourstart correspondent question. Standard errors are clustered by country. *,**, and *** denote significance at the $10 \%, 5 \%$ and $1 \%$ levels respectively. 


\section{TABLE 7: Correlation Matrix for GLS Labor Market Indices}

\section{Correlation coefficient and Spearman rank correlation among the labor market indices}

\begin{tabular}{|c|c|c|c|c|c|c|c|c|c|c|}
\hline $\begin{array}{r}\text { Correlation coefficient } \\
\text { Spearman's rho }\end{array}$ & $\begin{array}{l}\text { Role of IMF } \\
\text { \& World } \\
\text { Bank }\end{array}$ & $\begin{array}{c}\text { Labor } \\
\text { Market } \\
\text { Conditions }\end{array}$ & $\begin{array}{l}\text { Freedom of } \\
\text { Association } \\
\text { \& Collective } \\
\text { Bargaining }\end{array}$ & $\begin{array}{l}\text { Labor } \\
\text { Disputes }\end{array}$ & $\begin{array}{l}\text { Employment } \\
\text { Regulations } \\
\text { \& Working } \\
\text { Conditions }\end{array}$ & $\begin{array}{l}\text { Employee } \\
\text { Benefits }\end{array}$ & $\begin{array}{l}\% \text { informal } \\
\text { sector }\end{array}$ & $\begin{array}{l}\text { \% labor } \\
\text { union }\end{array}$ & $\begin{array}{l}\% \text { collective } \\
\text { bargaining }\end{array}$ & $\begin{array}{l}\text { Personal } \\
\text { Views \& } \\
\text { Positions }\end{array}$ \\
\hline General Economic & $-0.3500 * *$ & $0.8249 * * *$ & $0.6616^{* * *}$ & $0.3520 * *$ & $0.6023 * * *$ & $0.8271 * * *$ & $-0.8022 * * *$ & $0.5629 * * *$ & $0.6223 * * *$ & 0.1413 \\
\hline Situation & $-0.3165^{*}$ & $0.7834 * * *$ & $0.6902 * * *$ & $0.3827 * *$ & $0.6197 * * *$ & $0.8392 * * *$ & $-0.6949 * * *$ & $0.6026 * * *$ & $0.6521 * * *$ & 0.1664 \\
\hline Role of IMF \& World & & -0.2399 & -0.2153 & 0.0661 & -0.0305 & -0.2423 & 0.1568 & -0.0916 & -0.2108 & $-0.3019 *$ \\
\hline Bank & & -0.2737 & -0.1735 & 0.1183 & -0.0094 & -0.2119 & 0.1103 & -0.1735 & -0.1735 & -0.2136 \\
\hline \multirow[t]{2}{*}{ Labor Market Conditions } & & & $0.8557 * * *$ & $0.5692 * * *$ & $0.8485^{* * *}$ & $0.7453 * * *$ & $-0.8305 * * *$ & $0.6023 * * *$ & $0.7780 * * *$ & 0.1984 \\
\hline & & & $0.8740 * * *$ & $0.6063 * * *$ & $0.8593 * * *$ & $0.7707 * * *$ & $-0.8419 * * *$ & $0.5428 * * *$ & $0.8018 * * *$ & 0.1708 \\
\hline Freedom of Association \& & & & & $0.7293 * * *$ & $0.8618 * * *$ & $0.8040 * * *$ & $-0.7134 * * *$ & $0.5295^{* * *}$ & $0.8173 * * *$ & $0.3826^{* *}$ \\
\hline Collective Bargaining & & & & $0.7403 * * *$ & $0.8626 * * *$ & $0.8352 * * *$ & $-0.7607 * * *$ & $0.5334 * * *$ & $0.8215 * * *$ & 0.2858 \\
\hline \multirow[t]{2}{*}{ Labor Disputes } & & & & & $0.7575 * * *$ & $0.5978 * * *$ & $-0.4529 * * *$ & $0.4521 * * *$ & $0.7414 * * *$ & 0.2298 \\
\hline & & & & & $0.7737 * * *$ & $0.6103 * * *$ & $-0.5311 * * *$ & $0.4923 * * *$ & $0.7283 * * *$ & 0.1454 \\
\hline Employment Regulations & & & & & & $0.7067 * * *$ & $-0.7107 * * *$ & $0.5977 * * *$ & $0.8755^{* * *}$ & 0.2203 \\
\hline \& Working Conditions & & & & & & $0.7223 * * *$ & $-0.7483 * * *$ & $0.6120 * * *$ & $0.8810 * * *$ & 0.1604 \\
\hline \multirow[t]{2}{*}{ Employee Benefits } & & & & & & & $-0.6836 * * *$ & $0.5580 * * *$ & $0.7446 * * *$ & 0.1957 \\
\hline & & & & & & & $-0.7296 * * *$ & $0.5291 * * *$ & $0.7366 * * *$ & 0.1631 \\
\hline \multirow[t]{2}{*}{$\%$ informal sector } & & & & & & & & $-0.4670 * * *$ & $-0.6478 * * *$ & -0.2874 \\
\hline & & & & & & & & $-0.4365^{* *}$ & $-0.6838 * * *$ & -0.1581 \\
\hline \multirow[t]{2}{*}{$\%$ labor union } & & & & & & & & & $0.7403 * * *$ & -0.0195 \\
\hline & & & & & & & & & $0.7660 * * *$ & 0.1143 \\
\hline \multirow[t]{2}{*}{$\%$ collective bargaining } & & & & & & & & & & 0.2270 \\
\hline & & & & & & & & & & 0.2283 \\
\hline
\end{tabular}

Notes: In each cell, the first figure is the correlation coefficient between the two indices, while the second figure is the Spearman rho rank correlation statistic. *, $* *$, and $* * *$ denote p-values significant at the $10 \%, 5 \%$ and $1 \%$ levels respectively for tests against the null hypothesis that the indices are independent.

Calibrated indices are used except for "Personal Views \& Positions", where the mean of responses from each country across the Module 7 questions is used. 


\section{TABLE 8: Consistency of GLS Indices with Measures of the Regulation of Labor}

\section{Correlation coefficient and Spearman rank correlation among the labor market indices}

\begin{tabular}{|c|c|c|c|c|c|c|c|c|c|c|}
\hline $\begin{array}{r}\text { Correlation coefficient } \\
\text { Spearman's rho }\end{array}$ & $\begin{array}{l}\text { General } \\
\text { Economic } \\
\text { Situation }\end{array}$ & $\begin{array}{c}\text { Role of IMF } \\
\& \text { World } \\
\text { Bank }\end{array}$ & $\begin{array}{c}\text { Labor } \\
\text { Market } \\
\text { Conditions }\end{array}$ & $\begin{array}{c}\text { Freedom of } \\
\text { Association \& } \\
\text { Collective } \\
\text { Bargaining }\end{array}$ & $\begin{array}{l}\text { Labor } \\
\text { Disputes }\end{array}$ & $\begin{array}{l}\text { Employment } \\
\text { Regulations } \\
\text { \& Working } \\
\text { Conditions }\end{array}$ & $\begin{array}{l}\text { Employee } \\
\text { Benefits }\end{array}$ & $\begin{array}{l}\% \text { informal } \\
\text { sector }\end{array}$ & $\begin{array}{l}\% \text { labor } \\
\text { union }\end{array}$ & $\begin{array}{l}\% \text { collective } \\
\text { bargaining }\end{array}$ \\
\hline \multicolumn{11}{|l|}{ Botero et al. (2004): } \\
\hline $\begin{array}{l}\text { Employment laws } \\
\text { index }\end{array}$ & $\begin{array}{l}0.1408 \\
0.1924\end{array}$ & $\begin{array}{l}0.0360 \\
0.0726\end{array}$ & $\begin{array}{c}0.3376^{*} \\
0.3515^{* *}\end{array}$ & $\begin{array}{l}0.3966 * * \\
0.4450 * *\end{array}$ & $\begin{array}{l}0.4640 * * * \\
0.4901 * * *\end{array}$ & $\begin{array}{l}0.5196 * * * \\
0.4813 * * *\end{array}$ & $\begin{array}{l}0.3945 * * \\
0.4472 * *\end{array}$ & $\begin{array}{l}-0.0976 \\
-0.2111\end{array}$ & $\begin{array}{c}0.4019 * * \\
0.2676\end{array}$ & $\begin{array}{l}0.6363 * * * \\
0.5704 * * *\end{array}$ \\
\hline $\begin{array}{l}\text { Collective relations } \\
\text { laws index }\end{array}$ & $\begin{array}{l}-0.2174 \\
-0.1560\end{array}$ & $\begin{array}{c}0.2417 \\
0.3295^{*}\end{array}$ & $\begin{array}{c}-0.0618 \\
0.0506\end{array}$ & $\begin{array}{l}0.1801 \\
0.2055\end{array}$ & $\begin{array}{c}0.3464 * \\
0.3615^{* *}\end{array}$ & $\begin{array}{l}0.2145 \\
0.2262\end{array}$ & $\begin{array}{l}0.0525 \\
0.0541\end{array}$ & $\begin{array}{l}0.1368 \\
0.0374\end{array}$ & $\begin{array}{l}-0.0619 \\
-0.1239\end{array}$ & $\begin{array}{l}0.1688 \\
0.1155\end{array}$ \\
\hline $\begin{array}{l}\text { Social security laws } \\
\text { index }\end{array}$ & $\begin{array}{l}0.6178 * * * \\
0.6488 * * *\end{array}$ & $\begin{array}{l}-0.3690 * * \\
-0.2804\end{array}$ & $\begin{array}{l}0.5556 * * * \\
0.5279 * * *\end{array}$ & $\begin{array}{l}0.5882 * * * \\
0.5620 * * *\end{array}$ & $\begin{array}{c}0.4494 * * * \\
0.4476 * *\end{array}$ & $\begin{array}{l}0.4725^{* * *} \\
0.4666^{* * *}\end{array}$ & $\begin{array}{l}0.6802 * * * \\
0.6943 * * *\end{array}$ & $\begin{array}{l}-0.5618^{* * *} \\
-0.5121^{* * *}\end{array}$ & $\begin{array}{l}0.5529 * * * \\
0.6312 * * *\end{array}$ & $\begin{array}{l}0.5885 * * * \\
0.5883 * * *\end{array}$ \\
\hline $\begin{array}{l}\% \text { Employment in the } \\
\text { unofficial economy }\end{array}$ & & & & & & & & $\begin{array}{l}0.7591 * * * \\
0.6703 * * *\end{array}$ & & \\
\hline Union Density (ILO) & & & & & & & & & $\begin{array}{l}0.8240 * * * \\
0.7584 * * *\end{array}$ & \\
\hline $\begin{array}{l}\text { Right to collective } \\
\text { bargaining }\end{array}$ & & & & & & & & & & $\begin{array}{l}-0.1152 \\
-0.1605\end{array}$ \\
\hline $\begin{array}{l}\text { Doing Business: Rigidity } \\
\text { of Employment Index }\end{array}$ & $\begin{array}{l}-0.4779 * * * \\
-0.4001 * *\end{array}$ & $\begin{array}{c}0.3987 * * \\
0.4748 * * *\end{array}$ & $\begin{array}{l}-0.2783 \\
-0.2212\end{array}$ & $\begin{array}{l}-0.0889 \\
-0.0431\end{array}$ & $\begin{array}{l}0.1265 \\
0.1276\end{array}$ & $\begin{array}{l}0.0340 \\
0.0406\end{array}$ & $\begin{array}{l}-0.0873 \\
-0.0630\end{array}$ & $\begin{array}{c}0.3682 * * \\
0.2593\end{array}$ & $\begin{array}{l}-0.0857 \\
-0.1507\end{array}$ & $\begin{array}{l}0.0991 \\
0.0604\end{array}$ \\
\hline $\begin{array}{l}E F W \text { : Labor Market } \\
\text { Regulations }\end{array}$ & $\begin{array}{l}-0.0812 \\
-0.0784\end{array}$ & $\begin{array}{l}-0.1546 \\
-0.1905\end{array}$ & $\begin{array}{l}-0.2092 \\
-0.2481\end{array}$ & $\begin{array}{l}-0.3253^{*} \\
-0.3306^{*}\end{array}$ & $\begin{array}{c}-0.3345^{*} \\
-0.3713^{* *}\end{array}$ & $\begin{array}{l}-0.4189^{* *} \\
-0.4212^{* *}\end{array}$ & $\begin{array}{l}-0.3650 * * \\
-0.3746 * *\end{array}$ & $\begin{array}{l}0.1245 \\
0.1789\end{array}$ & $\begin{array}{c}-0.3704 * * \\
-0.2937\end{array}$ & $\begin{array}{l}-0.4229 * * \\
-0.3607 * *\end{array}$ \\
\hline
\end{tabular}

Notes: In each cell, the first figure is the correlation coefficient between the two indices, while the second figure is the Spearman rho rank correlation statistic. *,

**, and *** denote $\mathrm{p}$-values significant at the $10 \%, 5 \%$ and $1 \%$ levels respectively for tests against the null hypothesis that the indices are independent. 
TABLE 9: Summary Statistics of Labor Market Indices by Country Income Brackets

\begin{tabular}{|c|c|c|c|c|c|c|c|c|c|c|}
\hline & $\begin{array}{c}\text { General } \\
\text { Economic } \\
\text { Situation }\end{array}$ & $\begin{array}{c}\text { Role of IMF } \\
\& \text { World } \\
\text { Bank }\end{array}$ & $\begin{array}{c}\text { Labor } \\
\text { Market } \\
\text { Conditions }\end{array}$ & $\begin{array}{l}\text { Freedom of } \\
\text { Association } \\
\text { \& Collective } \\
\text { Bargaining }\end{array}$ & $\begin{array}{c}\text { Labor } \\
\text { Disputes }\end{array}$ & $\begin{array}{l}\text { Employment } \\
\text { Regulations } \\
\text { \& Working } \\
\text { Conditions }\end{array}$ & $\begin{array}{c}\text { Employee } \\
\text { Benefits }\end{array}$ & $\begin{array}{l}\% \text { informal } \\
\text { sector }\end{array}$ & $\begin{array}{c}\% \text { labor } \\
\text { union }\end{array}$ & $\begin{array}{l}\% \text { collective } \\
\text { bargaining }\end{array}$ \\
\hline Mean: All & 4.223 & 3.153 & 4.379 & 4.631 & 4.038 & 5.070 & 4.204 & 2.040 & 2.356 & 2.656 \\
\hline Quartile 1 & 2.719 & 3.362 & 3.643 & 3.858 & 3.744 & 4.534 & 3.018 & 3.175 & 1.919 & 1.634 \\
\hline Quartile 2 & 4.231 & 3.425 & 4.257 & 4.433 & 4.086 & 5.065 & 4.167 & 1.841 & 2.063 & 2.265 \\
\hline Quartile 3 & 4.838 & 3.014 & 4.903 & 5.117 & 4.188 & 5.475 & 4.764 & 1.573 & 2.498 & 3.466 \\
\hline Quartile 4 & 5.027 & 2.827 & 4.650 & 5.053 & 4.114 & 5.156 & 4.797 & 1.628 & 2.927 & 3.159 \\
\hline Developing & 2.980 & 3.392 & 3.696 & 3.862 & 3.742 & 4.504 & 3.145 & 2.967 & 1.759 & 1.513 \\
\hline $\begin{array}{r}\text { High-income } \\
\text { non-OECD }\end{array}$ & 4.677 & 3.348 & 4.307 & 4.128 & 3.685 & 4.934 & 4.215 & 1.795 & 2.358 & 2.280 \\
\hline OECD & 4.881 & 2.963 & 4.813 & 5.212 & 4.297 & 5.446 & 4.849 & 1.527 & 2.720 & 3.439 \\
\hline Median: All & 4.628 & 3.117 & 4.429 & 4.717 & 4.008 & 5.107 & 4.284 & 1.742 & 2.223 & 2.368 \\
\hline Quartile 1 & 2.627 & 3.418 & 3.684 & 3.854 & 3.795 & 4.503 & 3.085 & 3.189 & 1.934 & 1.452 \\
\hline Quartile 2 & 4.423 & 3.357 & 4.335 & 4.594 & 4.059 & 5.143 & 4.334 & 1.664 & 2.187 & 2.203 \\
\hline Quartile 3 & 4.802 & 3.004 & 5.001 & 5.260 & 4.558 & 5.882 & 5.021 & 1.266 & 2.252 & 4.114 \\
\hline Quartile 4 & 5.066 & 2.958 & 4.566 & 5.220 & 4.151 & 5.106 & 5.121 & 1.464 & 2.459 & 3.528 \\
\hline Developing & 2.682 & 3.452 & 3.788 & 3.877 & 3.719 & 4.579 & 3.103 & 2.887 & 1.891 & 1.445 \\
\hline $\begin{array}{r}\text { High-income } \\
\text { non-OECD }\end{array}$ & 4.704 & 3.234 & 4.335 & 4.008 & 3.657 & 5.074 & 4.807 & 1.502 & 2.106 & 2.146 \\
\hline OECD & 4.856 & 3.051 & 4.772 & 5.244 & 4.328 & 5.608 & 4.997 & 1.464 & 2.301 & 3.700 \\
\hline $\begin{array}{l}\text { Standard } \\
\text { Deviation: All }\end{array}$ & 1.046 & 0.477 & 0.661 & 0.828 & 0.573 & 0.697 & 1.058 & 0.835 & 0.998 & 1.279 \\
\hline
\end{tabular}

Notes: Summary statistics in bold are for the sample of 33 countries. Countries are sorted into quartiles based on the observed distribution of mean real GDP per capita (in constant 2000 US\$) for the years 2001-2003, taken from the World Development Indicators (WDI), with Quartile 1 corresponding to the lowest income quartile etc. The sorting of countries into Developing, High-income non-OECD and OECD countries is based on the World Bank's classifications; there were 11, 4, and 18 countries in these respective categories. Although the WDI does not report income data for Taiwan, we placed Taiwan in Quartile 3 and classified it as a high-income non-OECD country, together with Singapore, given that the CIA World Factbook estimates PPP-adjusted real GDP per capita between Taiwan and Singapore in 2004 to be very similar (US\$23,400 for Taiwan and US\$23,700 for Singapore). 


\section{TABLE 10: OLS Regressions between GLS Indices and Outcome Variables}

\begin{tabular}{|c|c|c|c|c|c|c|c|c|}
\hline \multirow[t]{2}{*}{$\begin{array}{l}\text { Dependent Variable: } \\
\text { Additional controls: }\end{array}$} & \multicolumn{2}{|c|}{$\begin{array}{c}\ln (\text { Mean real GDP per capita, } \\
\text { 2001-2003) }\end{array}$} & \multicolumn{2}{|c|}{$\ln ($ GINI coefficient $)$} & \multicolumn{2}{|c|}{$\begin{array}{l}\text { Mean growth rate of real GDP } \\
\text { per capita, 2000-2003 } \\
\ln (\text { Real GDP per capita, 2000) }\end{array}$} & \multicolumn{2}{|c|}{$\begin{array}{c}\text { Unemployment rate, } 2001 \\
\ln (\text { Real GDP per capita, 2001) }\end{array}$} \\
\hline & Coefficient & $\mathbf{R}^{2}$ & Coefficient & $\mathbf{R}^{2}$ & Coefficient & $\mathbf{R}^{2}$ & Coefficient & $\mathbf{R}^{2}$ \\
\hline General Economic Situation & $\begin{array}{l}0.971 * * * \\
(0.117)\end{array}$ & 0.65 & $\begin{array}{c}-0.122 * * * \\
(0.032)\end{array}$ & 0.37 & $\begin{array}{l}1.082 * * \\
(0.455)\end{array}$ & 0.32 & $\begin{array}{l}-2.294 \\
(1.548)\end{array}$ & 0.19 \\
\hline Role of IMF \& World Bank & $\begin{array}{c}-0.821 * * \\
(0.396)\end{array}$ & 0.10 & $\begin{array}{c}0.081 \\
(0.108)\end{array}$ & 0.02 & $\begin{array}{l}-0.228 \\
(0.850)\end{array}$ & 0.17 & $\begin{array}{c}1.743 \\
(1.255)\end{array}$ & 0.13 \\
\hline Labor Market Conditions & $\begin{array}{l}1.340 * * * \\
(0.230)\end{array}$ & 0.49 & $\begin{array}{l}-0.172 * * * \\
(0.038)\end{array}$ & 0.30 & $\begin{array}{c}0.724 \\
(0.523)\end{array}$ & 0.21 & $\begin{array}{c}2.336 \\
(1.851)\end{array}$ & 0.16 \\
\hline $\begin{array}{l}\text { Freedom of Association \& } \\
\text { Collective Bargaining }\end{array}$ & $\begin{array}{c}1.106^{* * * *} \\
(0.189)\end{array}$ & 0.51 & $\begin{array}{c}-0.112 * * * \\
(0.038)\end{array}$ & 0.20 & $\begin{array}{l}-0.052 \\
(0.514)\end{array}$ & 0.17 & $\begin{array}{l}4.071 * \\
(2.040)\end{array}$ & 0.34 \\
\hline Labor Disputes & $\begin{array}{l}0.832 * * * \\
(0.300)\end{array}$ & 0.13 & $\begin{array}{c}-0.113^{* *} \\
(0.052)\end{array}$ & 0.10 & $\begin{array}{c}0.473 \\
(0.387)\end{array}$ & 0.19 & $\begin{array}{l}2.773 * \\
(1.550)\end{array}$ & 0.20 \\
\hline $\begin{array}{l}\text { Employment Regulations \& } \\
\text { Working Conditions }\end{array}$ & $\begin{array}{c}1.040 * * * \\
(0.267)\end{array}$ & 0.31 & $\begin{array}{c}-0.125 * * * \\
(0.044)\end{array}$ & 0.17 & $\begin{array}{c}0.082 \\
(0.408)\end{array}$ & 0.17 & $\begin{array}{l}3.111^{*} \\
(1.669)\end{array}$ & 0.23 \\
\hline Employee Benefits & $\begin{array}{l}0.821 * * * \\
(0.189)\end{array}$ & 0.48 & $\begin{array}{c}-0.109 * * * \\
(0.034)\end{array}$ & 0.30 & $\begin{array}{c}0.309 \\
(0.336)\end{array}$ & 0.19 & $\begin{array}{l}-0.041 \\
(0.759)\end{array}$ & 0.11 \\
\hline$\%$ informal sector & $\begin{array}{l}-1.282 * * * \\
(0.127)\end{array}$ & 0.71 & $\begin{array}{c}0.097 * * \\
(0.045)\end{array}$ & 0.15 & $\begin{array}{l}-0.596 \\
(0.744)\end{array}$ & 0.19 & $\begin{array}{c}-2.090 \\
(2.070)\end{array}$ & 0.14 \\
\hline \% labor union & $\begin{array}{c}0.423 * * * \\
(0.148)\end{array}$ & 0.11 & $\begin{array}{c}-0.080 * * * \\
(0.026)\end{array}$ & 0.15 & $\begin{array}{c}0.416 \\
(0.291)\end{array}$ & 0.22 & $\begin{array}{c}0.474 \\
(0.808)\end{array}$ & 0.11 \\
\hline$\%$ collective bargaining & $\begin{array}{c}0.576 * * * \\
(0.132)\end{array}$ & 0.34 & $\begin{array}{c}-0.077 * * * \\
(0.020)\end{array}$ & 0.21 & $\begin{array}{c}0.033 \\
(0.220)\end{array}$ & 0.17 & $\begin{array}{c}1.026 \\
(0.668)\end{array}$ & 0.15 \\
\hline
\end{tabular}

Notes: Separate regressions are run for each dependent variable and each labor market index in turn. The coefficients on the labor market variables, robust standard errors and $\mathrm{R}^{2}$ values are reported. $* * *$, and $* * *$ denote significance at the $10 \%, 5 \%$ and $1 \%$ levels respectively. The number of observations for the regressions on income and the growth rate is 32, with Taiwan dropping out because of missing income data. The number of observations for the regressions on inequality is 29, with Austria, Cyprus, Israel and Switzerland dropping out because of missing inequality data. The number of observations for the regressions on the unemployment rate is 31 , due to missing unemployment data from India and Taiwan. 
FIGURE 1: Comparison of Percentage Estimates from the GLS and Botero et al. (2004)

Panel A: Size of informal sector

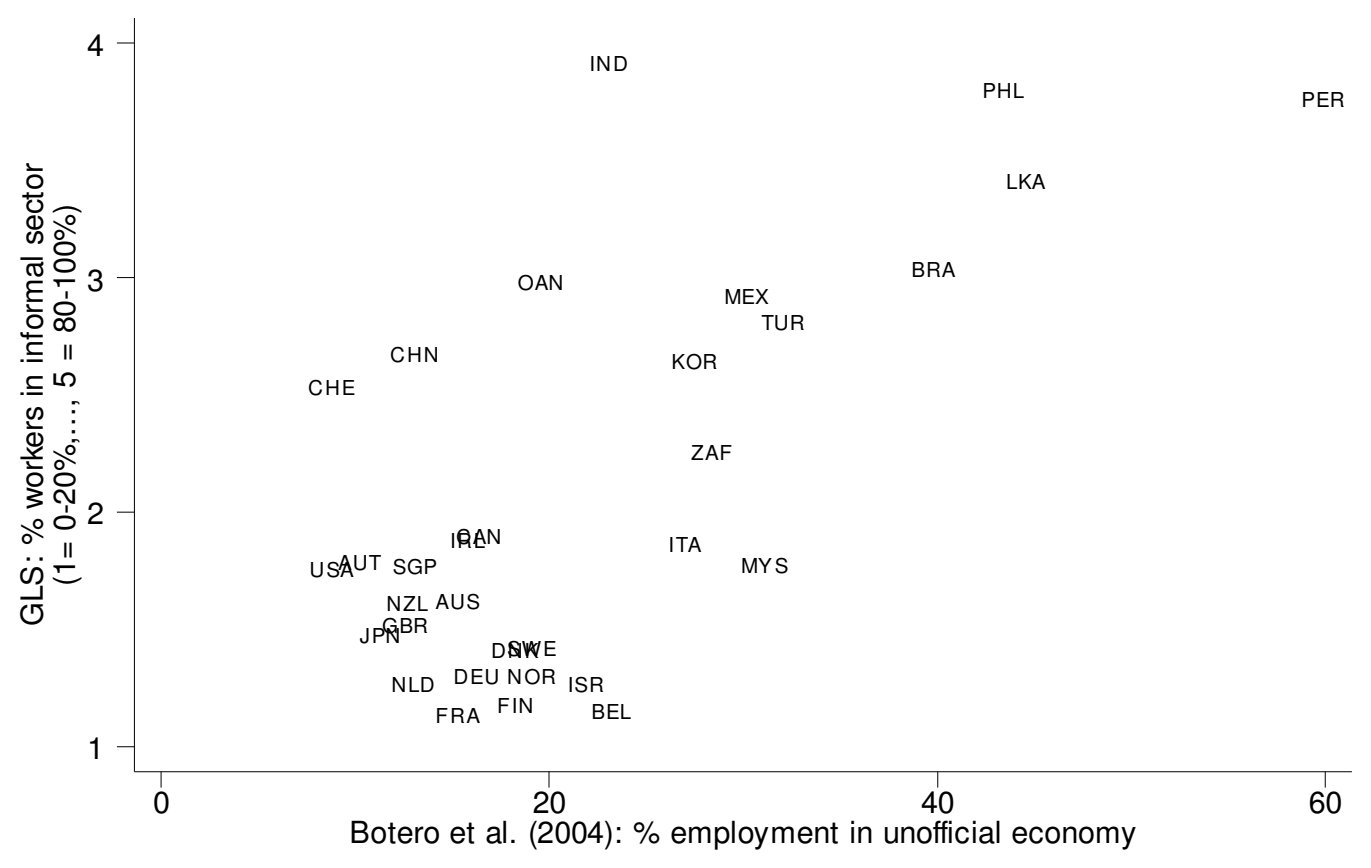

\section{Panel B: Unionization}

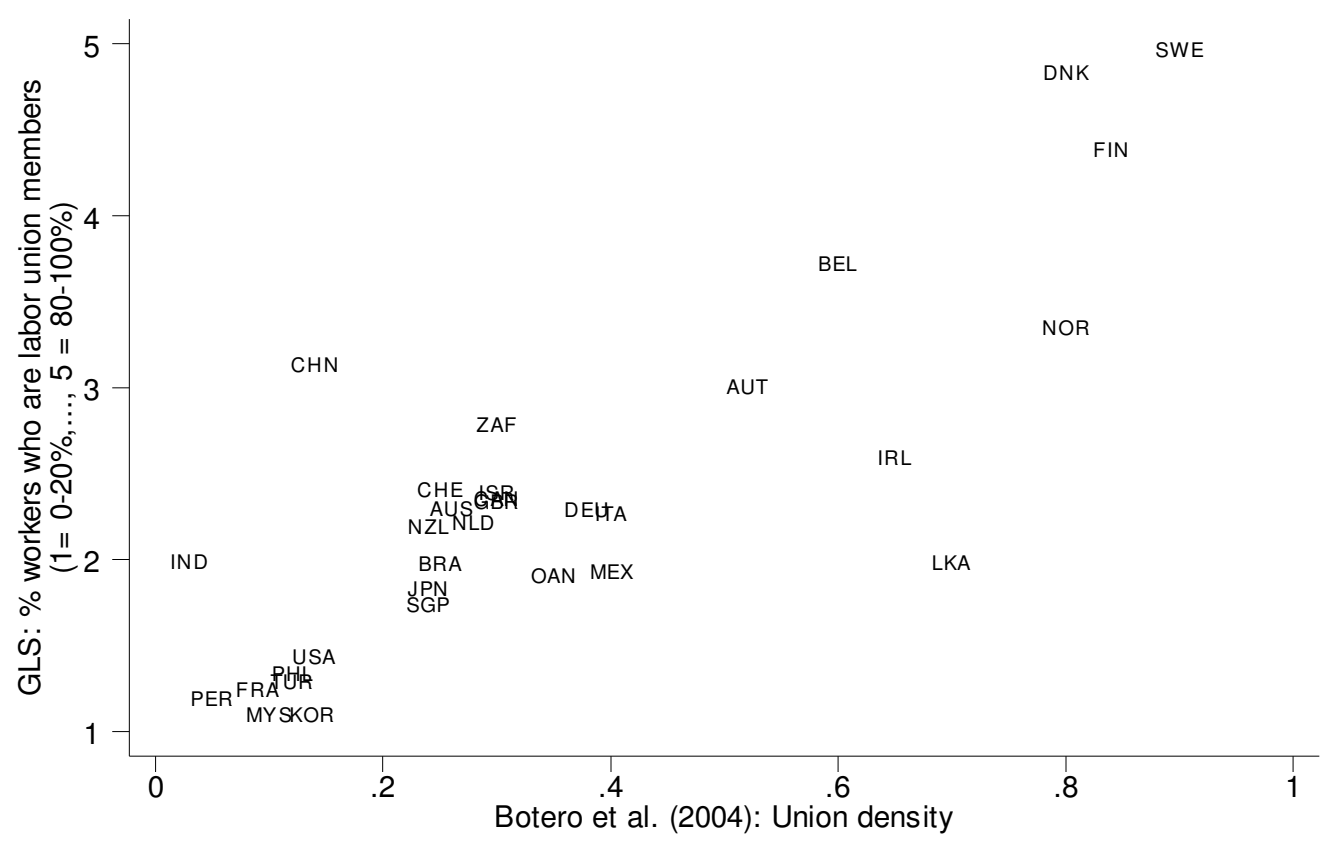




\section{APPENDIX TABLE 1: GLS Survey Questions}

For most of Modules 1 through 7, unless otherwise indicated, questions sought a response on a scale of 1 to 7 spanning the two polar opposite answer options provided. Interested readers are directed to the GLS website at http://gls.law.harvard.edu for a firsthand look at the survey instrument.

\begin{tabular}{|c|c|c|}
\hline & Survey question & Response options \\
\hline & Module 0: Respondent Information & \\
\hline 0.01 & Please identify the country on which you are reporting. & Pull-down list of countries provided. \\
\hline 0.02 & $\begin{array}{l}\text { How many years have you been studying or participating in the labor relations } \\
\text { of your country of expertise? }\end{array}$ & Less than 1 year ; 1 to 5 years ; 5 to 10 years ; More than 10 years \\
\hline 0.03 & How would you best describe yourself? & $\begin{array}{l}\text { Academic ; Corporate official ; Government official ; } \\
\text { Independent lawyer/arbitrator ; Journalist/Reporter ; Labor activist ; } \\
\text { Labor union official ; Other }\end{array}$ \\
\hline \multirow[t]{2}{*}{0.04} & Are you a Labourstart correspondent? & Yes ; No \\
\hline & Module 1: The General Economic Situation & \\
\hline 1.01 & In 2004, your economy has so far & $\begin{array}{l}1=\text { Been in a recession } \\
7=\text { Been strong }\end{array}$ \\
\hline 1.02 & The level of unemployment in your country is currently & $\begin{array}{l}1=\text { High and a major social and economic problem } \\
7=\text { Low and not a major social or economic problem }\end{array}$ \\
\hline 1.03 & The rate of poverty in your country is currently & $\begin{array}{l}1=\text { High and a major social and economic problem } \\
7=\text { Low and not a major social or economic problem }\end{array}$ \\
\hline 1.04 & $\begin{array}{l}\text { The difference in the quality of healthcare available to rich and poor people in } \\
\text { your country is }\end{array}$ & $\begin{array}{l}1=\text { Large } \\
7=\text { Small }\end{array}$ \\
\hline 1.05 & $\begin{array}{l}\text { The difference in the educational opportunities available to children from rich } \\
\text { and poor families in your country is }\end{array}$ & $\begin{array}{l}1=\text { Large } \\
7=\text { Small }\end{array}$ \\
\hline 1.06 & The quality of public schools in your country is & $\begin{array}{l}1=\text { Very bad } \\
7=\text { Equal to the best in the world }\end{array}$ \\
\hline
\end{tabular}


The role of foreign trade in your country's economy is

1.10 To what extent do World Bank and International Monetary Fund policies influence economic decision-making in your country?

1.11 Based on your experience, the World Bank's actions in your country have primarily helped the interests of

1.12 Based on your experience, the International Monetary Fund's actions in your country have primarily helped the interests of
$1=$ Poorly equipped to work in modern industry

$7=$ Equal to the best in the world at working in modern industry

$1=$ Seek opportunities to work abroad

$7=$ Remain and work in your country

$1=$ Limited or negligible

$7=$ Sizeable

$1=$ No influence on policy

7 = Large influence on policy

$1=$ The business sector

$7=$ Workers

$1=$ The business sector

$7=$ Workers

\section{Module 2: The Labor Market}

2.01

Hiring decisions in the PUBLIC or GOVERNMENT sector of your country are based mainly on

The minimum wage in your country is

Workers' pay levels in your country are

Pay in your country is

How often do workers in your country fail to receive the full amount of the REGULAR wages that they are supposed to be paid?

2.07 How often do workers in your country fail to receive the full amount of the OVERTIME wages that they are supposed to be paid?
$1=$ Personal connections

7 = Workers' skills, education or experience

$1=$ Personal connections

$7=$ Workers' skills, education or experience

$1=$ Evaded by firms

$7=$ Effectively enforced by the state or labor organizations

$1=$ Flexible and can be easily changed or re-negotiated

$7=$ Rigid and cannot be easily changed or re-negotiated

$1=$ Strongly related to worker productivity

$7=$ Not related to worker productivity

$1=$ Such problems are a regular occurrence

$7=$ Such problems are a rare occurrence

$1=$ Such problems are a regular occurrence

$7=$ Such problems are a rare occurrence 
2.08 The effect that globalization and trade have had on unskilled workers in your country has been

2.09 To what extent is the government in your country seeking to privatize traditional public sector jobs?

For questions 2.10, 2.11 and 2.12, the INFORMAL sector refers to workers who fall beyond the effective jurisdiction of labor and tax laws, either because they are self-employed or work for unofficial/unregistered businesses.

2.10 To your best knowledge, what percentage of workers in your country work in the INFORMAL sector? (PLEASE MARK ONE BOX ONLY)

2.11 The rights of workers in the INFORMAL sector

2.12 Wages in the FORMAL sector of your country are

2.13 Child labor or the employment of minors is

Discrimination on the basis of gender in the workplace is

Discrimination on the basis of race or ethnicity in the workplace is
$1=$ Generally negative

$7=$ Generally positive

$1=$ Not privatizing much

7 = Aggressively privatizing

$0-20 \% ; 21-40 \% ; 41-60 \% ; 61-80 \% ; 81-100 \%$

$1=$ Receive little attention from the state or labor organizations

$7=$ Are effectively protected by the state or labor organizations

$1=$ Set by individual companies that operate under market forces

$7=$ Set by a centralized bargaining process or by government statute

$1=$ A common and widespread practice

$7=$ Effectively prohibited

$1=$ A common and widespread practice

7 = Effectively prohibited

$1=$ A common and widespread practice

7 = Effectively prohibited

\section{Module 3: Freedom of Association \& Collective Bargaining}

3.01 To your best knowledge, what percentage of workers in your country are officially members of a labor union? (PLEASE MARK ONE BOX ONLY)

3.02 Labor unions in your country are

3.03

Protection of the right to form a union in your country is

Arrests or attacks on labor leaders because of their union activity are

In a unionized firm, are new employees allowed to choose whether they want to

$0-20 \% ; 21-40 \% ; 41-60 \% ; 61-80 \% ; 81-100 \%$

$1=$ Under the control of the state or political parties

7 = Independent organizations

$1=$ Weak or non-existent

7 = Equal to the world's most stringent

$1=$ Frequent

$7=$ Rare or non-existent

$1=$ Yes, employees have full personal choice 
oin a labor union?

The involvement of labor unions in politics in your country is

Labor unions in your country are generally

To your best knowledge, what percentage of the labor force is covered by a collective bargaining agreement? (PLEASE MARK ONE BOX ONLY)

Unions conduct negotiations with employers

In the process of determining wages in your country, labor unions

3.11

The extension of collective bargaining contracts to non-union firms is

3.12

Workers' participation in the management of companies (through such bodies as workers' councils) is

3.13

In practice, workers' opinions and suggestions on the management of companies

\section{Module 4: Labor Disputes}

4.01

Labor-employer relations in your country are generally

The population of your country at large generally

In your country, the threat of strikes is
$7=$ No, union membership is effectively mandatory in workplaces where a union is present

$1=$ Minimal or non-existent

$7=$ Frequent and substantial

$1=$ Ineffective in protecting and advancing the interests of workers $7=$ Effective in protecting and advancing the interests of workers

$0-20 \% ; 21-40 \% ; 41-60 \% ; 61-80 \% ; 81-100 \%$

$1=$ Under government influence or pressure

7 = Freely and independently of the government

$1=$ Are usually bypassed by employers

$7=$ Are very influential and powerful

$1=$ Not legislated

$7=$ Required and enforced by regulations

$1=$ Determined by employers

$7=$ Effectively enforced by the state or labor organizations

1 = Are usually bypassed by employers

$7=$ Are very powerful in influencing management decisions

$1=$ Cooperative

$7=$ Confrontational

$1=$ Does not support or care about labor unions

$7=$ Supports labor unions on the issues they raise

$1=$ Ineffective in increasing the bargaining power of labor unions and workers

$7=$ Very effective in increasing the bargaining power of labor unions and workers

$1=$ Rarely or never join in the strike 
$7=$ Often support union workers by participating in the strike

4.05 In your country, wildcat strikes (strikes that are not authorized by a formal labor union) are

4.06 In your country, political strikes (strikes for political reasons or in protest of government policies) are

4.07 Procedures requiring a waiting period or notification prior to conducting a strike are

In the event of a strike, how often do employers resort to hiring replacement workers?

4.09 In the event of a labor dispute, how often do employers resort to lockouts to place pressure on workers?

4.10 When workers fail to receive the full amount of their wages, how likely are they to obtain full repayment through courts or other administrative agencies?

4.11 The role of third-party mediation (such as labor arbitration courts) in resolving labor disputes is

4.12 Tripartite forums (involving labor, employers and the government) to help resolve labor disputes are

\section{Module 5: Employment Regulations \& Working Conditions}

5.01

The terms of contracts for hiring workers on a full-time basis are determined by

5.02

The extension of the benefits enjoyed by full-time workers to part-time worker is determined by

5.03

Hiring of workers on fixed-term contracts (employment for only a fixed period of time) is

5.04

Maximum hours of work in a regular workweek are determined by
$1=$ Rare or non-existent

$7=$ A common occurrence

$1=$ Rare or non-existent

$7=$ A common occurrence

$1=$ Required and enforced by regulations

$7=$ Non-existent or typically ignored by workers or labor unions

$1=$ Frequently

7 = Rarely

$1=$ Frequently

$7=$ Rarely

$1=$ Very unlikely to receive their full pay

$7=$ Very likely that a full resolution will be reached

$1=$ Non-existent or very limited

$7=$ Effective in resolving most disputes

$1=$ Non-existent or rarely used

$7=$ Often used to resolve disputes

$1=$ Employers

$7=$ Regulations or collective bargaining

$1=$ Employers

7 = Regulations or collective bargaining

$1=$ A common practice

$7=$ Rare or non-existent

$1=$ Employers

7 = Regulations or collective bargaining

$1=$ Employers 
$7=$ Regulations or collective bargaining

5.06 The number of days of paid vacation in a year for workers in FORMAL sector firms is determined by

5.07 Paid time off for national or local holidays is determined by

In practice, regulations on work hours and workplace conditions are

The labor standards and working conditions that foreign firms maintain in your country are

5.10 Firing of workers in the FORMAL sector of your country is determined by

5.11 Workers who believe they have been unfairly laid off

5.12 Do employers regularly notify a third party (such as a government agency or labor union) prior to a collective layoff of workers?

5.13 Do employers implement "seniority rules" when laying off workers, so that the newest hires are laid off first and senior workers laid off last?

5.14 Severance payment terms for dismissing full-time workers are determined by

5.15 Minimum health and safety standards in the formal sector are determined by

\section{Module 6: Employee Benefits}

6.01 The current level of state-determined benefits or pension for old-age, retirement, disability and death in your country is

In funding future social insurance pensions or retirement benefits, your country

$1=$ Employers

$7=$ Regulations or collective bargaining

$1=$ Employers

$7=$ Regulations or collective bargaining

$1=$ Ignored by employers

$7=$ Generally enforced

$1=$ Worse than those in domestic or state-owned firms

$7=$ Better than those in domestic or state-owned firms

$1=$ Employers

$7=$ The state or labor organizations

$1=$ Have no effective means to try to get their jobs back

$7=$ Can effectively try to get their jobs back through administrative or legal channels

$1=$ No, they never notify a third party

$7=$ Yes, they always notify a third party

$1=$ No, such decisions are entirely up to employers

$7=$ Yes, such seniority rules are always followed

$1=$ Employers

$7=$ Regulations or collective bargaining

$1=$ Employers

$7=$ Regulations or collective bargaining

$1=$ Insufficient to cover the needs of workers

$7=$ Sufficient to cover the needs of workers

$1=$ Faces a potential "pensions crisis"

$7=$ Has adequate funds to finance such future payments

$1=$ Rarely used or non-existent

$7=$ Widely used 
The current level of sickness and health benefits in your country is

6.06 In your country, unemployment benefits/unemployment insurance payments provided by employers for workers are determined by

6.07 The current level of unemployment benefits/unemployment insurance payments in your country is

6.08

Overall, the current level of social welfare benefits in your country is
$1=$ Determined in practice by employers

7 = Legally required and funded by tax revenues

$1=$ Insufficient to cover the needs of workers

$7=$ Sufficient to cover the needs of workers

$1=$ Employers

7 = Regulations or collective bargaining

$1=$ Insufficient to cover the needs of workers

$7=$ Sufficient to cover the needs of workers

$1=$ Lower than what your country's budgetary situation can afford $7=$ More than what your country's budgetary situation can afford

$1=$ Right-wing

7 = Left-wing

$1=$ Governments should allow market forces to determine economic outcomes

7 = Governments should intervene when market forces fail to achieve desired social outcomes

$1=$ Workers themselves

$7=$ Employers or the state

$1=$ Strongly disagree

$7=$ Strongly agree 


\section{APPENDIX TABLE 2: Matching of Questions with the Global Competitiveness Report}

\begin{tabular}{|c|c|c|c|}
\hline Subject & World Economic Forum 2004 Question & In WEF 2002? & GLS Qn match \\
\hline Growth outlook & $\begin{array}{l}2.01 \text { Your country's economy } \\
1=\text { Will likely be in recession in the next } 12 \text { months } \\
7=\text { Will have strong growth in the next } 12 \text { months }\end{array}$ & $\begin{array}{c}\text { Yes } \\
\text { Qn } 2.01\end{array}$ & 1.01 \\
\hline $\begin{array}{l}\text { Size of unofficial } \\
\text { economy }\end{array}$ & $\begin{array}{l}5.07 \text { The share of business activity in your country that you would estimate to be } \\
\text { unofficial or unregistered (including under-reported official revenue by registered firms) is: } \\
\text { Less than } 5 \% \text { of businesses ; 6-10\%;11-20\%;21-30\%;31-40\%;41-50\%; } 51-60 \% \text {; } \\
61-70 \% \text {; more than } 70 \%\end{array}$ & $\begin{array}{c}\text { Yes } \\
\text { Qn } 5.06\end{array}$ & 2.10 \\
\hline $\begin{array}{l}\text { Quality of public } \\
\text { schools }\end{array}$ & $\begin{array}{l}7.01 \text { The public (free) schools in your country are } \\
1=\text { Of poor quality } 7=\text { Equal to the best in the world }\end{array}$ & $\begin{array}{c}\text { Yes } \\
\text { Qn } 7.01\end{array}$ & 1.06 \\
\hline $\begin{array}{l}\text { Ease of hiring and } \\
\text { firing }\end{array}$ & $\begin{array}{l}7.02 \text { The hiring and firing of workers is } \\
1=\text { Impeded by regulations } \quad 7=\text { Flexibly determined by employers }\end{array}$ & $\begin{array}{c}\text { Yes } \\
\text { Qn } 7.02\end{array}$ & $\begin{array}{l}5.01 \\
5.10\end{array}$ \\
\hline $\begin{array}{l}\text { Labor-employer } \\
\text { relations }\end{array}$ & $\begin{array}{l}\text { 7.03 Labor-employer relations in your country are } \\
1=\text { Generally confrontational } \quad 7=\text { Generally cooperative }\end{array}$ & $\begin{array}{c}\text { Yes } \\
\text { Qn } 7.03\end{array}$ & 4.01 \\
\hline Wage-setting & $\begin{array}{l}7.04 \text { Wages in your country are } \\
1=\text { Set by a centralized bargaining process } \quad 7=\text { Up to each individual company }\end{array}$ & $\begin{array}{c}\text { Yes } \\
\text { Qn } 7.04\end{array}$ & 2.12 \\
\hline $\begin{array}{l}\text { Pay-productivity } \\
\text { relationship }\end{array}$ & $\begin{array}{l}\text { 7.05 Pay in your country is } \\
1=\text { Not related to worker productivity } \quad 7=\text { Strongly related to worker productivity }\end{array}$ & $\begin{array}{l}\text { Yes } \\
\text { Qn } 7.05\end{array}$ & 2.05 \\
\hline $\begin{array}{l}\text { Inequality in } \\
\text { healthcare access }\end{array}$ & $\begin{array}{l}7.10 \text { The difference in the quality of the healthcare available to rich and poor people in } \\
\text { your country is } \\
1=\text { Large } \quad 7=\text { Small }\end{array}$ & $\begin{array}{c}\text { Yes } \\
\text { Qn } 7.06\end{array}$ & 1.04 \\
\hline Quality of workforce & $\begin{array}{l}7.11 \text { The educational system in your country } \\
1=\text { Does not meet the needs of a competitive economy } \\
7=\text { Meets of the needs of a competitive economy }\end{array}$ & No & 1.07 \\
\hline
\end{tabular}




\begin{tabular}{|c|c|c|c|}
\hline Retention of talent & $\begin{array}{l}7.15 \text { Your country's talented people } \\
1=\text { Normally leave to pursue opportunities in other countries } \\
7=\text { Almost always remain in your country }\end{array}$ & $\begin{array}{c}\text { Yes } \\
\text { Qn } 7.09\end{array}$ & 1.08 \\
\hline $\begin{array}{l}\text { Gender discrimination } \\
\text { in the workplace }\end{array}$ & $\begin{array}{l}\text { 7.16 In your country, private sector employment of women is } \\
1=\text { Limited and usually takes place in less important jobs } \\
7=\text { Equal to that of men } \\
7.17 \text { In your country, for similar work, wages for women are } \\
1=\text { Significantly below those of men } \\
7=\text { Equal to those of men }\end{array}$ & No & 2.14 \\
\hline $\begin{array}{l}\text { Basis of hiring } \\
\text { decisions }\end{array}$ & $\begin{array}{l}10.14 \text { Senior management positions in your country are } \\
1=\text { Usually held by relatives } \\
7=\text { Held by professionals managers chosen based on superior qualification }\end{array}$ & $\begin{array}{c}\text { Yes } \\
\text { Qn } 10.14\end{array}$ & 2.01 \\
\hline Role of World Bank & $\begin{array}{l}\text { 12.01 The World Bank performs an effective role in promoting a pro-private sector } \\
\text { development/pro-investment climate } \\
1=\text { Very ineffective } \quad 7 \text { = Very effective } \\
12.02 \text { The World Bank performs an effective role in promoting socio-economic } \\
\text { development and poverty alleviation } \\
1=\text { Very ineffective } \quad 7=\text { Very effective }\end{array}$ & $\begin{array}{c}\text { Yes } \\
\text { Qn 12.01A } \\
\text { Qn 12.01B }\end{array}$ & $\begin{array}{l}1.10 \\
1.11\end{array}$ \\
\hline Role of IMF & $\begin{array}{l}\text { 12.03 The International Monetary Fund (IMF) performs an effective role in promoting a } \\
\text { pro-private sector development/pro-investment climate } \\
1=\text { Very ineffective } \quad 7=\text { Very effective } \\
12.04 \text { The International Monetary Fund (IMF) performs an effective role in promoting the } \\
\text { maintenance of high levels of employment and real income } \\
1=\text { Very ineffective } \quad 7=\text { Very effective }\end{array}$ & $\begin{array}{c}\text { Yes } \\
\text { Qn 12.02A } \\
\text { Qn 12.02B }\end{array}$ & $\begin{array}{l}1.10 \\
1.12\end{array}$ \\
\hline
\end{tabular}

